IZA DP No. 7636

Corruption, Networking and Foreign Ownership: Recent Evidence from CEE Countries

Sarmistha Pal

September 2013 


\title{
Corruption, Networking and Foreign Ownership: Recent Evidence from CEE Countries
}

\author{
Sarmistha Pal \\ University of Surrey \\ and IZA
}

\section{Discussion Paper No. 7636 \\ September 2013}

\author{
IZA \\ P.O. Box 7240 \\ 53072 Bonn \\ Germany \\ Phone: +49-228-3894-0 \\ Fax: +49-228-3894-180 \\ E-mail: iza@iza.org
}

Any opinions expressed here are those of the author(s) and not those of IZA. Research published in this series may include views on policy, but the institute itself takes no institutional policy positions. The IZA research network is committed to the IZA Guiding Principles of Research Integrity.

The Institute for the Study of Labor (IZA) in Bonn is a local and virtual international research center and a place of communication between science, politics and business. IZA is an independent nonprofit organization supported by Deutsche Post Foundation. The center is associated with the University of Bonn and offers a stimulating research environment through its international network, workshops and conferences, data service, project support, research visits and doctoral program. IZA engages in (i) original and internationally competitive research in all fields of labor economics, (ii) development of policy concepts, and (iii) dissemination of research results and concepts to the interested public.

IZA Discussion Papers often represent preliminary work and are circulated to encourage discussion. Citation of such a paper should account for its provisional character. A revised version may be available directly from the author. 


\section{ABSTRACT \\ Corruption, Networking and Foreign Ownership: Recent Evidence from CEE Countries ${ }^{1}$}

The present paper argues that the effect of corruption on foreign ownership is not necessarily linear and depends on the level of host corruption. So long as the expected returns from foreign investments exceed its expected costs, higher host corruption will be associated with higher foreign ownership. However, costs may exceed or exactly compensate the returns to foreign investment at very high level of corruption, giving rise to negative or even an insignificant relationship when positive and negative effects outweigh each other. Further, we argue that this non-linear corruption effects may arise from multinational firms' attempts to investing in countries with similar environment and/or ensuring some formal networking with host countries in a bid to limit the damages caused by high level of host corruption. Panel fixed effects estimates (after correcting for foreign entry selection) using a recent large homehost matched panel data from central and eastern European host countries provide some support to these hypotheses: (i) higher corruption is associated with significantly higher foreign ownership unless corruption is at its fourth quartile value. (ii) There is also some confirmation that this non-linear corruption effects is linked to parent firms' attempts to ensure institutional similarity while investing in corrupt host countries: in particular, foreign multinationals from EU/OECD home countries tend to hold higher ownership in EU/OECD host countries and also when the home-host relative corruption distance is small.

JEL Classification: F23, G32, L24, O17, P33

Keywords: corruption, relative corruption, EU/OECD home-host link, foreign ownership, joint venture vs sole subsidiaries, Central and Eastern Europe

Corresponding author:

Sarmistha Pal

Faculty of Business, Economics and Law

University of Surrey

Guildford GU2 7XH

United Kingdom

E-mail: s.pal@surrey.ac.uk

\footnotetext{
${ }^{1}$ The author gratefully acknowledges the financial support from the ESRC under RES-062-23-0986 and comments from Parimal Bag, Suman Banerjee, Randolph Bruno, Nigel Driffield, Beata Javorcik, Olga Kuzmina, Miriam Manchin at an early stage of the paper. We are also much grateful to Anastasia Semykina and Jeff Wooldridge for sharing the stata code used for the estimation of Wooldridge (1995) model. The usual disclaimer applies.
} 


\section{Introduction}

Globalization of production processes has gained rapid momentum in the 1990s, making it easier for foreign multinational companies to manage and control geographically dispersed production networks and supply chains. At the same time there has been a significant shift in the attitude towards foreign direct investment (FDI) to developing/emerging countries: the discussion among academics and policymakers has shifted from whether FDI should be encouraged to how developing countries can attract FDI. Many international development agencies including the World Bank now consider FDI as one of the most effective tools in the global fight against poverty.

There is a general consensus in the literature that greater host corruption increases the cost of doing businesses in a host country, which in turn may place some emerging economies with weak institutions at a relative disadvantage. Bribes paid to government officials could be regarded as additional taxes, which in turn waste essential resources as it does not increase productivity (see Murphy et al., 1991; Shleifer and Vishny, 1993 Wei, 1997). Rose-Ackermann (1999) argues that paying bribes may help a foreign firm to win a contract, but it also exposes it to future extortion attempts. The latter may be further aggravated by the fact that corruption contracts are not enforceable in courts (see Boycko et al., 1995). Higher costs increase the uncertainty of returns to foreign investment and may in turn lower a country's locational attractiveness (see Bardhan, 1997). As such, more corrupt host countries are less likely to attract foreign investment which receives some empirical support (e.g., Globerman and Shapiro, 1999; 2003; Bevan and Estrin, 2004; Aseidu, 2008).

However the effect of corruption is by no means unambiguous and may vary somewhat depending on the measure of FDI (size of FDI or size of foreign ownership), that of corruption or related risk factor and also the country of study (e.g., Wheeler and Mody, 1992; Hines 1995; Wei, 1997; Egger and Winner ; Javorcik and Wei, 2009). Nevertheless, it is difficult to deny that a large amount of FDI flows to countries with imperfect governance, e.g., those in Asia, Africa, Latin America (see Figure 1). In this context, we examine the nature and causes of this non-linearity, if any, in the relationship between corruption and foreign ownership. It is an important exercise as it is important to understand the extent to which corruption is a threat for attracting foreign investment, after taking account of all possible factors influencing foreign investment; otherwise the estimated effects of corruption is likely to be biased. In the process, the exercise also allows us to identify some possible mechanisms that may explain the perceived non-linear effects of corruption, thus yielding important policy implications.

It is argued here that corruption in many host countries is likely to have only limited impact on inward FDI unless the level of corruption is too high. This is because there are large potential gains to be had from these foreign investments especially when the host country has great potentials depending on the size of its economy and/or output growth rate. So long as the expected returns exceed the expected costs of foreign investment in a host country, the 
likelihood of foreign entry and also the size of foreign ownership may increase with host corruption, until corruption reaches a threshold. However, the entry and/or foeign ownership may fail to have a similar relationship when the level of corruption is too high when the costs of corruption may more than or exactly outweigh the returns to foreign investment; the latter may yield a negative or insignificant relationship. We argue that this non-liniearity in the corruptionforeign ownership relationship can, to some extent, be attributed to various mechanisms adopted by foreign multinationals, e.g., investing in countries with familiar environment and/or some formal/informal networking, with a view to limit the damages caused by host corruption and/or other unfamiliarity attached to foreign investment. Not surprisingly the effect of corruption on foreign entry, FDI or foreign ownership would be biased if these factors are ignored.

Recent empirical studies in the organizational behaviour literature (e.g., Boisot and Child, 1996) suggest that informal networks are often a response to inadequate institutional support. These networks usually involve an exchange of favors, making businesses easier for the members, thus reducing the risks of operating in a foreign environment. While exchange within the networks does not rely on explicitly written contracts, relationships between the members are guided by certain norms/conventions. Thus, a foreign firm may find it easier to invest in neighbouring countries with common border, common language and/or some diplomatic/cultural links, which may, to some extent, promote cross-border trust irrespective of higher host corruption.

Foreign multinationals may also make use of formal organisational networks to minimise the risks of investment in more corrupt host countries. This is because firms that form networked organisations can better protect themselves from corrupt officials. Associations thus become a medium of coordination, information transfer, and representation. They create safeguards for members against bureaucratic intervention and extortion. By pooling their resources, organized firms can better fight corruption by either increasing public awareness or employing legal protection. The more widespread the corruption is, the greater the gains derived from joining such associations will be. In this respect, we examine the benefits that parent firms from EU or OECD home and host countries may receive by investing in sample EU/OECD host countries in central and eastern Europe. In addition to the EU's commitment to stability of democracy, rule of law, human rights, protection of minorities and capacity to cope with competition and market forces, EU accession opens up the possibility of resolving any potential conflict by appealing to the European Court of Justice (rather than the national court in any of these CEE countries), thus hedging the fear of high corruption in the host nation, at least to some extent. Similar networking effect may be evident within OECD, where member countries are committed to democracy and market economy and are required to co-ordinate domestic and international policies of its members. OECD members are also responsible to comply with the multilateral agreement on investment and international actions on corruption and bribery abroad. Accordingly, parent firms from EU/OECD parent countries may seek to invest in EU/OECD host countries in the CEE region, as membership of these organizations stimulates the 
transfer of information among members about effective strategies of confronting corruption, helps develop legal protection mechanisms, provides better access to political decision makers to report instances of low level corruption, and makes bureaucratic misdeeds more visible.

Further, over the last two decades or so FDI (as proportion of total FDI outflows) from developing countries is sharply rising. UNCTAD data suggests that the share of FDI from developing countries has increased from about $6.19 \%$ in $1986-1990$ to about $18 \%$ by 2010 . The nature of such FDI is also changing, from being mainly in natural resource industries to being much more broadly based (Mlachila and Takebe 2011). This changing pattern may reflect the greater ability and experience of multinational firms from developing countries to cope with difficult economic environments characterised by weak institutions, which in turn may help them to cope with similar conditions elsewhere in many ways: (i) unlike foreign multinationals from developed countries, these developing country MNCs can better manage unreliable supply chains, unreliable power supplies, low-skilled and diverse workers in less developed host countries. (ii) They know the importance of contacts and relationships to navigate through regulatory obstacles and weak contract enforcement. (iii) Outward investors from developing countries are also used to bribery in their home countries, and are not normally constrained by their home-country laws in their foreign operations (unlike OECD anti-bribery law abroad, for example). In other words, parent firms from a corrupt home nation may find it easier to invest in a host country with similar corrupt environment. A possible indicator of institutional similarity between home and host nations could be the distance between home and host corruption. We thus hypothesize that the lower the distance between home and host corruption (i.e., the greater the familiarity of parent firms with corrupt host environment), the greater would be the parent firm's ability to cope with the corrupt host environment and hence more FDI into host countries irrespective of host corruption.

Using Orbis firm-level data from Bureau Van Djik for the period 2002-2008, we generate host-home matched information to test the hypotheses of interest. While there is a large number of existing studies examining the effect of corruption and/or weak governance on foreign investment, foreign entry or mode of foreign entry (Javorcik and Wei, 2009), most have assumed a linear relationship. ${ }^{2}$ In view of the non-parametric hump-shaped relationship between foreign ownership and host corruption noted in our sample (see Figure 3), we investigate if there is a minimum level of host corruption beyond which greater host corruption would lower foreign ownership. In this respect, we consider the quartile distribution of the host corruption index (e.g., Q2, Q3, Q4 relative to the reference category Q1) in our sample. ${ }^{3}$ As such, we exploit the variation in corruption across countries and over time to identify its causal effect on foreign

\footnotetext{
${ }^{2}$ Note however that theoretically Javorcik and Wei (2009) includes the possibility that there is no FDI when host corruption is too high although this hypothesis is not tested in the paper

${ }^{3}$ This is a general way of exploring the nature of asymmetry or non-linearity in analysing the relationship between two variables.
} 
ownership. Secondly, we attempt to explain the observed corruption-foreign ownership relationship in terms of various networking mechanisms adopted by foreign MNCs to cope with the possible adverse effects of host corruption: (i) EU/OECD membership link between host and home countries; (ii) home-host institutional similarlity; the latter is measured by the first quartile of the absolute distance between home and host corruption in our sample. Accordingly, in addition to the host corruption quartiles and these additional networking arguments, we include the interaction terms between each of these arguments (i)-(ii) and host corruption quartiles (Q2, Q3 and Q4). The latter allows us to identify the differential effect of each of these networking arguments (i)-(ii) in the presence of a given level of host corruption. Insignificance of any of these interaction coefficients would however highlight that the potential positive and negative effects of corruption outweigh each other in the presence of these forms of networking. We primarily use fixed effects OLS estimates of percentage foreign ownership (as a measure of foreign investment) with correction for selectivity bias (a la Wooldridge 1995) arising from foreign entry (only $16 \%$ of sample firms had some foreign ownership) decision. We also check the robustness of our estimates in various ways (see further discussion in section 4).

The existing literature typically focuses on corruption in host countries, which has been extended to related (and highly correlated) institutional measures of rule of law, property rights and political freedom. In general, most studies find an adverse effect of host corruption on FDI at country (Kaufman et al. 1999; Henisz, 2000; Globerman and Shapiro, 2003; Bevan and Estrin 2004) or firm (Heines 1995; Wei 1997, 2000) level, generally using single/pooled crosssection method. A few papers, however, find a positive impact of corruption on FDI in specific instances where thriving corruption may facilitate wealth creation by entrepreneurs. For example, Leff (1964) suggests that in the presence of regulations and other administrative controls, corruption can act as a helping hand to foster FDI. Multinational firms might be willing to pay bribes in order (i) to speed up bureaucratic process to obtain permission to set up business (Lui 1985) and (ii) to gain access to publicly funded projects (Tanzi and Davoodi, 2000), which is again highlighted by Egger and Winner (2005). Our analysis appears to integrate why both positive and negative effects of corruption may be possible as we account for possible networking mechanisms to explain the observed non-linear effects of corruption.

Correcting for the selectivity bias of entry, we find that Q2 and Q3 levels of corruption may be associated with significantly higher foreign ownership while Q4 level of corruption remains insignificant, thus confirming the hypothesis of non-linearity in corruption. Next, we examine if the networking hypothesis may explain this observed non-linearity. There is indeed some confirmation that foreign ownership is significantly higher when EU/OECD parent firms invest in EU/OECD host countries in our sample and the significance of corruption per se vanishes altogether in these cases. Also, we find that a lower distance in corruption between the home and the host countries (when the distance between home and host corruption is less than its first quartile value) is associated with a significantly higher foreign ownership as host corruption increases from 
Q1 to Q2 and Q3; however the effect turns out to be insignificant when host corruption is high at Q4 level, as we predicted. Our results are robust to using alternative corruption measures (ICRG and TI) as well as additional control variables including GDP, GDP growth rate, home-host common border. Access to panel data is clearly an advantage of our analysis over much of the existing literature, as it helps minimising the bias arising from the unobserved firm and year specific factors. We follow Wooldridge (1995) to obtain the selection corrected fixed effects estimates of foreign ownership and argue that these corrected estimates are superior to the alternative Tobin or Heckman selection estimates using pooled data.

In an attempt to compare our results with Javorcik and Wei (2009), the final section also determines two categorical foreign ownership variables (categorical variable FO, distinguishing SS from majority and minority JV, and a second binary variable FO_SS distinguishing between sole foreign subsidiary (SS) and foreign joint venture (JV)). These additional results are broadly in line with our basic results; these also highlight similarities and differences with Javorcik and Wei (2009). Ceteris paribus, we find that the within-sector likelihood of SS is lower at Q3 level of corruption for both FO and FO_SS though remains insignificant for Q4 level of corruption. However, the likelihood of SS is higher for Q2 and Q3 levels of corruption when there is low relative corruption. Evidently, these results hold even after controlling for sector fixed effects, so that we do not find a differential effect for technologically sophisticated firms in our sample. Clearly, this is a more general result than Javorcik and Wei (2009). We argue that this can be attributed to the panel structure of the data which captures the trade-off between SS and JV better, since there are important learning process involved. Further we argue that the additional cost of JV is not only pertinent for technologically sophisticated firms, but also for firms in other sectors, as the cost of leakage attached to JV may not only petain to technology transfer, but also that pertaining to management strategy, often through the labour market (Tsang, 1994). This is supported by our data, which is an important value added to the existing literature (see further discussion in section 4).

The rest of the paper is organized as follows. Section 2 explains the econometric model while Section 3 describes the data set used in the analysis and presents descriptive statistics. Section 4 presents the results while the final section concludes.

\section{Data Description}

The dataset used in this paper has primarily been drawn from ORBIS, which is a comprehensive and rich firm-level dataset and has been widely used (e.g. Helpman et al. 2004; Budd et al. 2005; Konings and Murphy 2006). It is provided by Bureau van Dijk $(\mathrm{BvD})^{4}$, a leading electronic publisher of annual account

\footnotetext{
${ }^{4} \mathrm{BvD}$ is best known for databases, such as BANKSCOPE and FAME, which are widely subscribed to by UK Universities. It can also be compared with COMPUSTAT which is extensively used in the US.
} 
information on several million private and public firms around the world.

Orbis shows firm-level ownership (direct as well as total) information by shareholder type (indicating country-of-ownership); it may further provide the parent-identification number in which case we were able to link the parent firm characteristics to the host firm. In cases where host firms have information on foreign ownership and ownership shares but do not show parent identification numbers or the information on the parent firm is not disclosed or limited, we are not able to include these firms in our analysis. Out of a total of 9185 manufacturing firms ${ }^{5}$ operating in $12 \mathrm{CEE}$ countries available from Orbis, 2,458 host firms were linked to a parent firm in our sample for $2002-2008^{6}$. This produces a large data-set of host firms drawn from 12 CEE host countries including Bulgaria, the Czech Republic, Estonia, Hungary, Lithuania, Latvia, Poland, Romania, Russia, Slovakia and Ukraine. ${ }^{7}$

Some of the sample host countries like Czech Republic, Estonia, Hungary, Lithuania, Latvia, Poland and Slovakia became EU members in 2004 while Bulgaria and Romania joined EU in 2007. There are some OECD members as well among the sample host countries and the list includes Czech Republic, Estonia, Hungary, Poland and Slovakia while Slovenia became one of the newest members of OECD as late as 2010; we did not include Slovenia as OECD country in our analysis as we focus on pre-2010 period.

There is a wide range of home countries in our sample. The list is dominated by foreign investors from the US and the old EU countries including France, Germany, Italy, Netherlands, UK, Denmark and Sweden. There are also parent firms from other OECD (e.g., Australia, Canada, Japan), newly emerging (e.g., Brazil, China, India and Russia) countries as well as those from the middle-east (e.g., Israel, Lebanon, Syria, Turkey). However, on average, home firms from various OECD countries dominate the sample host firms, comprising about of $87 \%$ of the total observations while $68 \%$ of sample host firms attract investment from firms from old EU countries.

Among various possible institutional features, our analysis of foreign ownership primarily focuses on the role of corruption. This has two advantages. First, corruption can be seen as a key single indicator of institutional quality as it reflects the impact of underlying institutional inputs including poor protection of property rights, excessive and arbitrary regulation, and weak informal institutions including social norms and values shaping human behaviour into one output indicator that describes the quality of the interface between businesses and public administration. Corruption is multi-dimensional and difficult to quantify. We primarily rely on corruption data from International Risk Country Guide (ICRG) compiled by Political Risk Services Group, which are consistent with measures available either directly from Transparency Interna-

\footnotetext{
${ }^{5}$ Manufacturing firms in our sample are defined as those categorised by sector 16-32.

${ }^{6}$ We choose this subsample as we need to use a balanced sample for estimation; see further discussion in section 3 .

${ }^{7}$ We did not include countries where we would have less than 5 firms (e.g. Macedonia, Moldova etc.). The smallest country in our sample has at least 100 firms at some point in the panel period.
} 
tional (TI) or from the Heritage Foundation/ Wall Street Journal (see footnote to Table 1 for the variable definition). ${ }^{8}$ The ICRG corruption index is concerned with the actual or potential corruption in the form of excessive patronage, nepotism, job reservations, 'favor-for-favors', secret party funding, and suspiciously close ties between politics and business. These insidious sorts of corruption are potentially of much greater risk to foreign business in that they can lead to popular discontent, unrealistic and inefficient controls on the state economy, and encourage the development of the black market. The index varies between a minimum of 1 to a maximum of 5 in our sample; we have adjusted the corruption index in such a way that a higher value of the index reflects higher corruption. Other corruption measures, e.g. Kaufmann et al. (1999) (which became Worldwide Governance Indicators project by World Bank) are also used (e.g., see Javorcik and Wei, 2009). Given the panel nature of our data, we could not use Kaufmann et al. (1999) measures as the time dimension is a particular problem. Kaufmann et al. (1999) standardise distributions for each year (with mean zero and standard deviation of one), so data is not comparable over time (see methodological description in Kaufmann et al., 2009). So we compare our results using the ICRG corruption indices with the comparable Transparency International (TI) corruption indices. The corruption perception index (CPI) by the TI draws on assessments and opinion surveys carried out by independent and reputable institutions. These surveys and assessments include questions related to the bribery of public officials, kickbacks in public procurement, embezzlement of public funds, and the effectiveness of public sector anti-corruption efforts. Perceptions are used because corruption is to a great extent a hidden activity that is difficult to measure. As with ICRG index, we adjust the CPI index in such a way that a higher value reflects higher level of corruption.

Table 1 summarises the means and standard deviations of both ICRG Transparency International (TI) corruption indices for individual CEE host countries in our sample. In general, most of the host countries have an index above 3 with the exception of Russia and Ukraine (both of which have an average over 4). The lowest ICRG corruption index is noted in Czech Republic. Second, as with ICRG index, an inter-country variation in the mean is noted in the distribution of CPI. In general the averages are comparable between these two alternative corruption indices; further, the pattern of this variation is roughly similar to those observed for ICRG corruption index: the lowest CPI is observed in Czech Republic, while the highest is in Ukraine (4.42), closely followed by Russia (4.17).

Foreign investment is measured by the percentage of foreign ownership in host firms in sample CEE countries. About $16 \%$ of sample host firms had some positive percentage share of foreign ownership. Panel a of Figure 2 shows the distribution of percentage of foreign ownership for all firms while that in panel $\mathrm{b}$ shows that for firms with some foreign ownership in our sample. These figures highlight the skewed nature of the distribution of foreign ownership. While more

\footnotetext{
${ }^{8}$ Using a sample of 32 developing countries, Morisset and Lumenga-Neso (2002) showed that higher costs and delays associated with various administrative barriers are strongly correlated with the prevailing level of corruption as captured by Transparency International Index.
} 
than $80 \%$ of sample firms do not have any foreign ownership, about $6 \%$ of all firms with foreign ownership are fully owned foreign subsidiaries. Considering the firms with some foreign ownership, the average percentage of foreign ownership is about $80 \%$ for the sample as a whole. Further, about $63 \%$ of all firms with positive foreign ownership have $90 \%$ or higher foreign ownership while as high as $56 \%$ of sample firms with positive foreign ownership have sole foreign ownership. There is also a significant inter-country variation in foreign ownership: the mean is as high as $89 \%$ in the Czech Republic closely followed by Poland (86\%), Slovakia (84\%), Estonia (83\%), Romania (82\%), Latvia (81\%) and Hungary (80\%), all being members of the EU-2004. At the other end of the scale, the lowest average foreign ownership is observed in Ukraine (58\%) followed by Bulgaria (62\%), which joined the EU in 2007. However, in general, the sample host countries, who are members of EU or OECD, tend to have higher average foreign ownership (around 85\%) compared to the overall average of about $80 \%$ for all CEE sample host countries taken together.

It is also interesting to explore the distribution of the home countries across host firms in our sample. While Baltic countries tend to have major investments from parent firms from Scandinavian countries, German firms are key investors in Central Europe (Czech Republic, Hungary, Poland), and Italian firms tend to invest predominantly in Romania. The latter seems to highlight an aspect of physical proximity, which may also entail some socio-cultural link most notably in terms of language between home and host firms. US parent firms are important exceptions, which are found in all the sample countries, but most notably in Latvia, Ukraine, Slovakia and Bulgaria.

Figure 3 shows the bivariate relationship between corruption and foreign ownership in our sample using both ICRG and TI indices. The Epanechnikov non-parametric kernel scatter plot between percentage foreign ownership and proper host corruption (scaled) highlights a non-linear relationship between host corruption and foreign ownership. Clearly there is very little variation in foreign ownership (within 5 percentage points) as corruption increases from 1 to 3.5 or so. The share of foreign ownership reaches its peak of about $83 \%$ when host corruption is around 3.5 and thereafter it falls steeply reaching a minimum of around $68 \%$ or so when the host corruption is around 4.5. Similar pattern is observed for the TI index as well. We take this as evidence of a non-linear pattern in the relationship beween corruption and foreign ownership in our sample where the adverse effect of corruption seems to be binding only when corruption index exceeds 3.5 or so.

\section{Empirical Model}

Having explored the data in section 2, we shall now consider some parametric models of foreign ownership to examine.

Our central hypothesis is to explore the link between corruption on the one hand and foreign ownership on the other and in this respect we are particularly interested to explore the nature of non-linear relationship, if any, as highlighted 
in Figure 3. It is however important to distinguish the decision to enter a host market from the size of the ownership held by foreign multinationals, which also determines the mode of entry. This is because only a fraction (about 16\%) of sample firms have some foreign ownership. If one is interested in identifying the effect of corruption (among others) as a possible determinant of foreign ownership of a particular group of sample firms, the difference between firms with and without foreign ownership would determine whether an issue of selection bias arises. To illustrate this, one needs to characterize each firm by endowments of observable and unobservable characteristics. If the firms with foreign investment have similar endowments of characteristics as those without, there is no reason to suspect selectivity bias will be induced by examining the subsample of firms with foreign investment. In other words, if the sample of firms with foreign investment is randomly chosen, the average characteristics, in terms of both observable and unobservables, of the subsample should be similar to the average characteristics of the population. Alternatively, one can consider the case where the foreign investment in a subsample of firms is no longer random and consequently the sample firms with and without foreign investment potentially have different characteristics. Sample selection bias arises when some component of the foreign entry decision is relevant to the process of determining the size of foreign ownership at the second stage; that is, when some of the determinants of the entry decision are also influencing the ownership. When the relationship between the entry decision and the size of foreign ownership is purely through the observables, one can control for this by including the appropriate conditioning variables in the ownership equation. Thus, sample selection bias will not arise purely because of differences in observable characteristics.

Clearly, presence of unobservable firm characteristics may also influence estimates of percentage of foreign ownership at the second stage. The latter is particularly problematic when these unobservable characteristics are correlated with the observable characteristics, leading to incorrect inference regarding the impact of the observables. In order to minimise this potential omitted variable bias, one needs to control for as many factors as possible. Fortunately, we have access to panel data where the value of foreign ownership may change over time. Hence, we can adopt the panel data fixed effects model that would allow us to identify the true effect of corruption by exploiting the within firm variation of unobserved factors over time.

However the standard panel data fixed effects models do not control for selectivity bias. Hence, we follow Wooldridge (1995) who devises a selectivity corrected fixed effects panel data model where the unobserved component is allowed to be correlated with observable explanatory variables in the primary ownership equation of interest. This is an improvement over Verbeek and Nijman (1992), who consider a random effects (RE) model under the assumptions of normality and serial independence of the idiosyncratic errors in both the selection and regression equations. Nijman and Verbeek (1992) and Zabel (1992) study almost the same model except they allow both unobserved effects to be correlated with the observables. Vella and Verbeek (1992) extend Nijman and Verbeek (1992) to allow for functions of the endogenous censoring variable to 
appear among the explanatory variables. In order to make the selection equation simple to estimate, Wooldridge (1995) makes a normality assumption on the errors in the selection equation, but allows these errors to display arbitrary serial correlation and unconditional heteroskedasticity. Given that foreign ownership information in our sample is bounded between 0 and 100 (in percentage term), the Heckman/Wooldridge model excludes the firms when foreign ownership is 0 . In particular, truncation at the second stage would imply that we ignore the part of the distribution when percentage foreign ownership is zero.

The primary equation of our interest pertains to the percentage foreign ownership $\mathrm{Y}_{i t}$ of $\mathrm{i}$-th firm in year t. Suppose $\mathrm{Y}_{i t}{ }^{*}$ is the latent endogenous variable attached to the observed counterpart of $\mathrm{Y}_{i t}$, which is a function of a set of exogenously given explanatory variables $\mathrm{X}_{i t}$ and where errors $\mathrm{u}_{i t}$ are independently and identically distributed:

$$
Y_{i t}^{*}=\beta^{\prime} X_{i t-1}+\delta_{i}+u_{i t},
$$

where $\mathrm{i}=1,2, \ldots ., \mathrm{N}$ and $\mathrm{t}=1,2, \ldots ., \mathrm{T}$. Equation (1) includes one period lagged values of explanatory variables $\mathrm{X}$ as we try to minimise any potential bias arising from the simultaneity between $\mathrm{Y}$ and $\mathrm{X}$ variables. The model explicitly covers the case where $\delta_{i}$ is allowed to be correlated with $\mathrm{X}_{i t}$, so that all elements of $\mathrm{X}_{i t}$ are time-varying; this allows for time dummies and interactions of time dummies with time-invariant variables. If all $\mathrm{T}$ periods are available for any cross-section drawn from the population, a sufficient condition for fixed effects (and a variety of other procedures) to be consistent as $\mathrm{N} \rightarrow \infty$ is: $\mathrm{E}\left(\mathrm{u}_{i} / \delta_{i}, \mathrm{X}_{i 1}, \ldots, \mathrm{X}_{i T}\right)$ $=0$, for all $\mathrm{t}=1,2, \ldots, \mathrm{T}$. Under this assumption, fixed effects estimates are consistent as $\mathrm{N} \rightarrow \infty$. For the usual FE standard errors and test statistics to be valid one would also need a second assumption that $\mathrm{E}\left(\mathrm{ui}, \mathrm{ui} / \delta_{i}, \mathrm{X}_{i}\right)=\sigma^{2} \mathrm{I}_{T}$.

Let us now introduce the possibility of selection in this framework. Suppose the vector of selection is given by $\mathrm{F}_{i}=\left(\mathrm{F}_{i 1}, \mathrm{~F}_{i 2}, \ldots ., \mathrm{F}_{i T}\right)^{\prime}$ such that $\left(\mathrm{X}_{i t}, \mathrm{Y}_{i t}\right)$ is observed only when $\mathrm{F}_{i t}=1$ for $\mathrm{t}=1,2, \ldots ., \mathrm{T}$. Here $\mathrm{F}_{i t}$ takes a value 1 if the $\mathrm{i}$-th host firm has some foreign ownership in a given year $t$ and 0 otherwise. Thus foreign ownership $\mathrm{Y}_{i t}$ is observed only when the firm has any foreign investment. Suppose for a given $\mathrm{t}, \mathrm{t}=1,2, \ldots, \mathrm{T}, \mathrm{F}_{i}^{*}$ is a latent variable attached to $\mathrm{F}_{i}$, which is determined as follows:

$$
F_{i}^{*}=\alpha^{\prime} Z_{i}+v_{i}
$$

In equation (2) $Z_{i}$ is the set of explanatory variables explaining $F_{i}$ in a given year $\mathrm{t}$. Z could include all variables included in $\mathrm{X}$ or could be a subset of $\mathrm{X}$. Technically this does not affect one's ability to carry out correcting for selection bias, but it helps if one has exclusion restrictions in (2), which are not included in (1).

The set of explanatory variables $\mathrm{Z}$ used for the determination of the selection equation of foreign entry at the first stage includes characteristics of host firms (size, age, real cash flow, share of intangible assets, market share, TFP) and also host corruption measures Q2, Q3 and Q4 . Note that real cash flow of host firms are not included in $\mathrm{X}$ as this is likely to be more pertinent for the entry rather 
than the size of the ownership decision. $\mathrm{Z}$ also includes an index of host country infrastructure which is likely to be a direct determinant of locational decision of foreign multinationals. This is because access to existing public infrastructure in a host country will reduce costs of production and hence is likely to boost higher rate of return to foreign investment, other factors remaining unchanged. Further, Z does not include parent firms' characteristics as these are relevant only for determination of foreign ownership equation (1) at the second stage. First, we estimate the selection equation (2) of foreign entry $\mathrm{F}_{i}$ for each year $\mathrm{t}, \mathrm{t}=2002, \ldots .2008$, which in turn enables us to derive a year-specific estimate of $\lambda_{i t}$, i.e., the inverse Mill's ratios (IMRs).

At the second stage selecting firms with some foreign onwerhsip, i.e., when $\mathrm{F}_{i}=1$, the selection corrected foreign ownership will be determined as follows:

$$
Y_{i t}^{*}=\beta^{\prime} X_{i t-1}+\gamma^{\prime} \overline{x_{i}}+\theta^{\prime} \lambda_{i t}+\Sigma_{i} T_{i}+\Sigma_{i} \lambda_{i t} * T_{i}+u_{i t}
$$

where we insert the $\lambda_{i t}$, i.e., the inverse Mill's ratios (IMRs) generated from the first stage estimates of equation $(2) . T_{i}$ is a time dummy that takes value 1 for the i-th year and 0 otherwise. Note that the value of ownership depends not only on the lagged $\mathrm{X}_{i t-1}$ variables, but also on the firm-specific time averages of $\mathrm{X}_{i t}$ characteristics, i.e., $\bar{x}_{i}$, along with the time dummies $\mathrm{T}_{i}$ as well as their interactions with the IMRs. The set of control variables $\mathrm{X}$ refers to the selected characteristics of host firms (e.g., firm size, market share, TFP and share of intangible assets) as well as those (e.g., (size, share of intangible assets) for the parent firms . Further, we include a binary variable to control for the host country's adherence, if any, to competition policy as this can particularly induce a foreign multinational to invest more in a host country. More importantly, assuming that the fixed effects $\delta_{i}$ depend on the time averages of $\mathrm{X}_{i t}$, i.e., $\left(\overline{x_{i}}\right.$ ), over $\mathrm{t}=1,2, \ldots \ldots, \mathrm{T}$, Wooldridge (1995) establishes that the simplest consistent estimate of (3) would be a pooled OLS. All standard errors are clustered at the host firm level, which allows us to control for the correlation, if any, in errors over time for a given firm. Successful implementation of Wooldridge (1995) requires us to generate a balanced panel and hence we only use the sample of firms which has complete information for the period 2002-08.

Wooldridge (1995) proved that the relevant $\mathrm{FE}$ estimates from equation (1) would be consistent and asymmetrically normal as $\mathrm{N} \rightarrow \infty$ only if $\mathrm{E}\left(\mathrm{u}_{i} / \delta_{i}, \mathrm{X}_{i}\right.$, $\left.\mathrm{F}_{i}\right)=0$ for $\mathrm{t}=1,2, \ldots, \mathrm{T}$. Also, for the usual fixed effects variance- covariance matrix and inference to be valid, a sufficient additional assumption is $\operatorname{Var}\left(\mathrm{u}_{i} / \delta_{i}\right.$, $\left.\mathrm{X}_{i}, \mathrm{~F}_{i}\right)=\sigma^{2} \mathrm{I}_{T}$.

\subsection{Hypotheses}

Clearly Figure 3 highlights the non-linearity in the relationship between corruption and foreign ownership in our sample in terms of kernet plot. In order to model this parametrically, we create three measures of corruption from the quartile of distributions of each corruption index, ICRG as well as TI, namely, 
second (Q2), third (Q3) and fourth (Q4) quartile values of these corruption indices. Accordingly, we modify equation (3) as follows:

$$
Y_{i t}^{*}=\beta_{1} C Q_{2}+\beta_{2} C Q 3+\beta_{4} C Q 4+\beta^{\prime} W_{i t-1}+\gamma^{\prime} \overline{x_{i}}+\theta^{\prime} \lambda_{i t}+\Sigma_{i} T_{i}+\Sigma_{i} \lambda_{i t} * T_{i}+u_{i t}
$$

We expect that the sign and significance of the estimated coefficients of these corruption quartile variables, namely, CQ2, CQ3 and CQ4, will account for the non-linear effect of corruption, if any, on foreign ownership (relative to the reference category CQ1, i.e., corruption quartile 1) at the second stage. We may expect, without any loss of generality, that some level of corruption may encourage higher foreign ownership leading to sole foreign subsidiary, which may not hold at a higher level of corruption (which was also assumed by Javorcik and Wei, but was not empirically tested). In the absence of any prior evidence, we use our data to explore the relationship between corruption and foreign ownership in our sample (see Table 4 for these results). ${ }^{9}$

Next we examine the possible factors explaining the observed non-linear corruption-foreign ownership relationship as highlighted in Figure 3. In this respect, we take account of the possible networking mechanisms adopted by foreign multinationals to cope with the adverse effects of host corruption. These estimates are summarized in specifications (1)-(5) in Table 6 (see further discussion in section 4). First, we consider the lowest quartile (rc_q1) of absolute distance between home and host corruption to account for the institutional similarlity between home and host countries (see column 1 of Table 6). As such, we also interact the first quartile of relative corruption rc_q1 with Q2, Q3 and Q4 values of host corruption (rc_q $1^{*}$ corruption_q2, rc_q $1^{*}$ corruption_q3, rc_q1*corruption_q4). Next, we consider the cases of formal networking between foreign firms from old EU member countries and as such, we augment (3) by a binary variable eu_eu that takes value 1 if EU home countries invest in EU host countries; we also include the interactions of eu_eu with the three quartile values of host corruption (eu_eu_corruption_q $\overline{2}$, eu_eu_corruption_q3 and eu_eu_corruption_q4); these estimates are summarized in column $\overline{2}$ of the table. In alternative specifications, we do the same for OECD parent firms investing in OECD host firms and generate a second binary variable oecd_oecd (see column 3 of Table 6 ). Along similar lines, we also consider the possibility that a parent firm from EU/OECD countries may invest in any EU/OECD host firms and to this end generate a third binary variable both_eu_oecd (see column (4) of Table 6 and further discussion in section 4). As before, we also include the interaction between oecd_oecd (or both_eu_oecd) and host corruption quartiles (Q2, Q3, Q4). The final column (5) of Table 6 shows the estimates of the most complete specification: here we include both measures of institutional simialarity (rc_q1) as well as EU/OECD home-host networking arguments together with their respective interactions with the host corruption quartiles Q2, Q3, Q4. The underlying idea is that networking with EU/OECD

\footnotetext{
${ }^{9}$ In section 4.4 we simulate the Javorcik and Wei (2009) case using our data to highlight the similarity and differences of our study from theirs.
} 
countries or host countries with similar corruption environment is likely to reduce the cost of entry as well setting up a new plant in a corrupt host country, at least to some extent; the latter in turn may enhance the attractiveness of sole foreign subsidiary (SS) as opposed to joint venures (JV).

We start our estimates using ICRG corruption indices and then test the robustness of our results by comparing the initial results with those obtained by using the alternative CPI measures provided by TI. Further we compare the Wooldridge panel data fixed effects estimates of the baseline foreign ownership (\%) regression with the corresponding pooled Heckman and tobit estimates with a view to identify the advantages of Wooldridge, which not only controls for selectivity bias, but also minimises the omitted variable bias (see Table 5). Table 6 (columns 1-5) then shows the Wooldridge firm/year and also firm*year (that captures firm-specific trends) FE estimates of percentage foreign ownership using various networking arguments as decribed above. Some may however raise concern that home-host networking between EU/OECD countries or countries with similar corruption environment may be correlated with the index of eocnomic development of the host country. We find that, if any, the correlation between GDP and EU/OECD membership of host countries is likely to be rather indirect as the EU/OECD entry criteria is not directly based on GDP, but related to competitive environment and institutional requirement. In fact, the sample correlations between host EU and OECD membership with GDP turn out to be 0.13 and 0.02 respectively. Nevertheless we test the robustness of our estimates by augmenting the model specification by GDP, GDP growth (see estimates summarised in AppendixTable A3), if any. Given that host GDP and GDP growth also determine the returns from foreign investment, it also allows us to identify the net effect of corruption with a view to test the robustness of our baseline results.

Given that we use firm fixed effects, we envisage that missing country-level characteristics will be confounded in the firm-level fixed effects. Some may still argue that there could be time-varying omitted factors which may still bias our estimates. Note that we have already included firm-specific time dummies as captured by firm*year fixed effects, which we hope would control for the firmlevel time-varying omitted factors. For the remaining time-varying omitted factors, our estimates will still go through so long as these omitted factors are negatively correlated with the error term, in which case our estimates will be biased downwards; if so, our estimates could be regarded as the lower bound of the true estimates.

Finally, we compare of our results with Javorcik and Wei (2009) and as such construct some catgorical (FO) and binary (FO_SS) ownership variables differentiating sole foreign subsidiary from various types of JV (majority and minority). The underlying idea is that greater corruption will increase the cost of sole foreign subsidiary not only in setting up a new plant, but also of doing day-to-day businesses in a corrupt host country, all by itself. Witout much loss of generality, it can however be assumed that over time these additional costs of SS may decline as the foreign investor gets familiar with the system. In contrast, higher host corruption may may increase the relative attractiveness 
of joint venture (JV) where one may receive some help and support from the local collaborators to deal with local bureaucrats; however, at the same time, JV may involve some additional cost of information leakage (related to both technology and management strategy), which may also increase over time. As such it is important to use panel data methods as ours to understand the effect of corruption on mode of foreign entry, which is further discussed in section 4.4.

Both between firms and within-firm means and standard deviations of all regression variables are summarized in Table 2.

\section{Results and Discussion}

In this section we analyse the estimates with a view to interpret them vis-a-vis the central hypotheses of interest. In an attempt to minimise the simultaneity bias, if any, all explanatory variables are lagged by one year; also, all standard errors are clustered at the firm level with a view to minimise the correlation of errors over years for a given firm.

\subsection{First stage estimates of foreign entry}

The distribution of foreign ownership is rather skewed to the right. For example, out of a total firm-year observations of 387831, there are 63027 firmyear observations with some positive foreign ownership in our sample so that the total observations with foreign ownership greater than or equal to $1 \%$ is about $16.25 \%$ in our sample. We accordingly generate a Foreign entry variable called Foreign 1 which takes a value 1 if foreign ownership is greater than or equal to $1 \%$ and 0 otherwise. Since only about $16 \%$ of sample firms had some foreign ownership, first we estimate probit foreign entry estimates for Foreign1 for each of the sample years as shown in Table 3 using ICRG corruption index (the corresponding Foreign 1 estimates using TI are shown in Appendix Table A1).

In order to explore the non-linear relationship between host corruption and foreign ownership, we consider the quartile distribution of each of the corruption indices. This is a natural way to explore the non-linearity rather than arbitrarily imposing our own threshold values. In our sample 2nd quartile (Q2) value of ICRG corruption index is 3.5 while the corresponding third quartile (Q3) value is 4 . Clearly there is some variation in the effect of corruption on the likelihood of foreign entry across the sample years. Ceteris paribus, we find that greater host corruption is not necessarily associated with lower likelihood of foreign entry. In particular, host corruption Q2, Q3 and Q4 levels are associated with significantly higher likelihood of foreign entry respectively in the years 2002-07, 2003-05 and 2006-08. The estimates for Q4 level of corruption is interesting: while the estimate of Q4 was negative in the earlier years (2003-05), but turned positive and signficant from 2006 onwards as the EU accession process deepened. We obtain comparable results when using TI corruption index.

Among other results, there is suggestion that younger, larger and more productive host firms are more likely to attract any foreign investment; also, greater cashflow of the host company is associated with higher while greater market 
share with lower likelihood of foreign entry. Wile R\&D of the host firm does not seem to play any significant role here, better access to host infrastructure significantly improves the prospect of attracting foreign investment in our sample. In general, these results confirm our expectations.

We use both ICRG and TI indices to generate two sets of inverse Mill's ratios for each firm for each year, which are then used to construct the IMR term $\lambda_{i t}$ to estimate equation (3), i.e., the selectivity corrected estimates of foreign ownership (see section 4.2 below) .

4.2. Selectivity corrected panel FE-OLS Wooldridge estimates of foreign ownership

Selectivity corrected estimates of percentage foreign ownership are summarised in Table 4. Columns (1)-(2) of Table 4 show the estimates using ICRG index while those in columns (3)-(4) show estimates using TI corruption index. Since the selection correction term lambda is significant in both cases, we couch our discussion in terms of the corrected estimates shown in columns (2) and (4) respectively for ICRG and TI corruption indices. Considering the estimates obtained using ICRG indices, we particularly focus on the signs and significance of the corruption coefficients in column (2): both Q2 and Q3 levels of ICRG corruption are associated with significantly higher foreign ownership while Q4 corruption coefficients remain insignificant. When we use TI corruption index, only Q2 level of corruption is significant while Q3 and Q4 remain insignificant in determining percentage of foreign ownership. In other words, there is no evidence from this analysis that corruption necessarily lowers foreign ownership in our sample. In contrast, results suggest that some degree of low to moderate levels of corruption (Q2, Q3) is associated with significantly higher foreign ownership until corruption is too high. It is with respect to Q4 (for ICRG index) and Q3 and Q4 for (TI index) we find that corruption does not bear a significant impact on the size of foreign ownership. We argue that this insignificance can be attributed to an indifference where costs of corruption may exactly outweigh the returns from foreign investment at a higher level of corruption.

Robustness check: Wooldridge estimates highlight that there is significant self-selection in our sample arising from the selective foreign entry, thus rendering uncorrected estimates of foreign ownership to be irrelevant. Next we proceed to compare Wooldridge panel fixed effects estimates of foreign ownership with the corresponding pooled Tobit and Heckman selection estimates commonly used in the literature: while both of these alternative models allow for some selection correction, they do not take account of the within firm variation in outcomes over time. These estimates are summarised in Table 5. It is noteworthy that pooled tobit identifies a significant negative effect of Q3 host corruption, while the corresponding effect is negative but not significant in the pooled Heckman model. In contrast, the effect is positive and statistically significant in panel FE Wooldridge model. Similar effect is obtained with respect to Q4 value of host corruption. We argue that this Wooldridge corrected estimates are superior to these alternative estimates, as none of these alternative estimates control for firm fixed-effects and as such are likely to suffer from the 
omitted variable bias.

Accordingly, exploiting the within firm variation in foreign ownership over time, the selectivity corrected Wooldridge point estimates for percentage foreign ownership are 2.26 and 1.81 higher when ICRG corruption indices are respectively at its Q2 and Q3 levels. In other words, one standard deviation increase in Q2 level of corruption is associated with $1 \%$ higher foreign ownership; the corresponding figure is about $0.78 \%$ for one standard deviation increase in Q3 level of corruptin. However, the significantly favourable effect of corruption for foreign ownership vanishes when ICRG corruption is at Q4 (i.e., when the index is greater than 4). The insignificance of the Q4 corruption coefficient may pertain to a case when the costs of corruption loom large and exactly outweigh the returns from foreign investment. Given that these estimates are obtained after controlling for firm and year specific fixed effects and also possible selectivity bias, we argue that these estimates provide the causal effects of corruption on percentage foreign ownership in our sample.

\subsection{Role of Networking- selectivity corrected FE-OLS estimates of foreign ownership}

We next test the validity of the networking hypothesis with a view to explore its link with non-linear corruption-foreign ownership relationship. Table 6 summarises the corrected estimates of foreign ownership where we augment the basic model shown in Table 4 by including the networking arguments: homehost networking link (EU, OECD or both), and also low absolute difference in home and host corruption. In order to find out the differential effects of corruption in these cases, if any, we also interact these networking factors with the levels of host corruption Q2, Q3, Q4. These estimates are summarsied in Table 6.

As before, the selection correction term lambda is statistically significant and negative in each column of the table, thus justifying the use of the two-step corrected Wooldridge FE estimates of percentage foreign ownership. Each specification (1)-(5) augment Table 4 specifications by including various networking arguments individually/jointly and also their interactions with the host corruption quartiles. First, column (1) tests if firms from source countries with similar level of corruption as CEE host countries (i.e., when the difference in host and home relative corruption is low) tend to have higher foreign ownership in a host country. To this end, we include a dummy rc_q1 that takes a value 1 if the distance between home and host corruption is less than or equal to the Q1 value of the variable 1.5; otherwise the variable takes a value 0 . While rc_q1 per se is not statistically significant in our sample, its interactions with Q2 and Q3 levels of host corruption are positive and significant. These estimates suggest that parent firms from home countries with similar level of corruption as that of a host country would hold significantly higher foreign ownership in our sample, even when host corruption increases from Q1 to Q2 and then to Q3. Note however that the interaction term is no longer significant for Q4 level of host corruption so that the significant positive effect of institutional similarity between host and home country vanishes. 
Next we consider if networking between EU, OECD and/or both EU and OECD home-host link would significantly boost foreign ownership when host corruption is high. To this end, we create 3 dummy variables: EU_EU=1 if both source and host countries are EU members; OECD_OECD $=1$ if if both source and host countries are OECD members and also both_EU_OECD $=1$ if both home and host countries are EU or OECD members. We also create interactions between these binary EU/OECD link membership variables and Q2, Q3, Q4 levels of host corruption, with a view to explore if the significance of host corruption vanishes in these cases of networking between EU/OECD home and host countries. Columns (2)-(4) show the corrected Wooldridge foreign ownership estimates as we respectively consider EU-EU, OECD-OECD and both EU and OECD home-host links. As expected, EU EU link is positive and significant (column 2) while OECD_OECD link (column 3) is not. However when we consider both EU and OEC $\bar{D}$ link together as in column (4), the binary variable both_eu_oecd is positive and statistically significant, thus suggesting that home-host EU /OECD networking may significantly boost foreign ownership in our sample. Also, note that none of the interaction terms between networking and host corruption (Q2, Q3, Q4) is statistically significant in columns (2)-(4); the latter suggests that the adverse effect of corruption vanishes when EU/OECD home countries invest in EU/OECD host countries.

Finally column (5) shows the estimates of foreign ownership when we augment column (4) specification by rc_q1 and also their interactions with host corruption quartiles Q2, Q3 and Q4. We also include control for common border and also its interaction with both_eu_oecd; as such this is the most complete specification that we prefer. As before, there is suggestion that the estimated interaction coefficients are positive and significant for Q2 and Q3 levels of corruption, but not when corruption is at its Q4 value. In other words, there is suggestion that foreign ownership increases significantly when homehost corruption environment is similar. Second, the dummy for both_eu_oecd is positive and significant so that foreign ownership is significantly higher when both home and host countries are EU and/or OECD members. Further, the interaction terms between Q2 and Q3 levels of corruption are both positive, thus suggesting a positive association between Q2 and Q3 level of corruption when both home and host countries are EU/OECD members. However, the interaction with Q4 host corruption is dropped here. These estimates from the complete specification seem to corborate the corruption-foreign ownership relationship observed in Table 4. Clearly, there is a significant premium attached to institutional familiarity in our sample. The corresponding estimates using TI index of corruption are summarised in Appendix Table A2 turn out to be quite comparable to the estimates obtained by using ICRG corruption index, thus confirming the robustness of our foreign ownership estimates.

Appendix Table A3 additionally include host GDP and its annual growth rate. Host countries with greater GDP offer bigger market and hence may attract more foreign investment because the expected rates of return from this investment is likely to be higher. Similarly, host countries with greater economic growth rate offers greater potential for foreign investment. While log GDP 
is positive and statistically significant in columns (1) and (2), GDP growth rate is positive, but statistically insignificant. Our central corruption results remain largely similar even when we include these additional controls, highlighting the significant differential effects of networking: institutional similarity and EU/OECD networking for Q2 and Q3 level of corruption. However, the etimated host corruption coefficient turns out to be negative and significant for Q3 level of corruption per se, while the corruption Q4 coefficient remains statistically insignificant in both columns. Taken together the total effect of corruption when $\mathrm{rc}_{\mathrm{q}} \mathrm{q} 1=1$ and also both home and host countries belong to EU/OECD turn out to be $5.428 \%$ and $4.113 \%(=-4.321+8.434)$ respectively for Q2 and Q3 levels ICRG corruption (where we consider only the significant and relevant estimated coefficients corruption, corruption*rc q1 and corruption*both_eu_oecd). The corresponding effects for CPI corruption index turn out to be $5.941 \%$ and $4.248 \%$ respectively for Q2 and Q3 levels of CPI corruption. Clearly, these effects are more than double than what we found in Table 4: one standard deviation increase in corruption Q2 will be associated with $2.446 \%$ higher foreign ownership; the corresponding figure for corruption Q3 will be associated with $1.77 \%$ higher foreign ownership. Nevertheless, the underlying corruption-foreign ownership relationship remains non-linear around corruption quartile Q4.

4.4. Choice between sole foreign subsidiary vs. joint ventures some corrected estimates

Our data show that the average foreign ownership is very high among the firms with some foreign ownership in almost all host countries. It is as high as $89 \%$ in the Czech Republic while the lowest figure is $58 \%$ in Ukraine. Hence, on average, foreign investors tend to have absolute majority ownership rights in sample firms. The actual control rights of foreign investors may not be much different when they have $90 \%$ cash flow rights and when they have $60 \%$ cash flow rights. In an attempt to compare our results with Javorcik and Wei, we next estimate two more specifications. First, we construct a binary indicator for sole foreign subsidiary FO_SS. The variable takes a value 1 if foreign ownership is greater than or equal to $90 \%$ and zero otherwise (the value of the variable is missing for firms with less than or equal to $1 \%$ foreign ownership). Second, we not only classify foreign-owned firms into wholly-owned (SS) vs. joint ventures (JV), but also distinguish joint ventures into majority foreign-owned (51-99.99) and minority foreign-owned (10-50.99). Accordingly, we construct a categorical variable $\mathrm{FO}$ as follows:

$\mathrm{FO}=3$ if SS

$=2$ if majority $\mathrm{JV}$

$=1$ if minority $\mathrm{JV}$

$=0$ if foreign ownership $<=9.99 \%$, but greater than $1 \%$

Naturally, we estimate a binary probit model to determine FO_SS while an ordered probit model to determine FO, since FO is ordered by construction (in terms of the underlying threshold parameters $\rho_{1}, \rho_{2}$ and $\rho_{3}$ ). In both cases, we considered pooled estimates of these variables for the period 2002-08 and 
include as many control variables as possible so that the omitted variable bias is minimised. As before, we use a set of lagged explanatory variables which not only includes $\mathrm{X}$ as in equation 1 , but also includes natural logarithm of GDP and its growth rate to account for the potential gain from investing in the host country. Further we control for sector and year controls to account for sector- and year-level variation in foreign ownership. Since we focus on the firms with foreign ownership greater than $1 \%$, we also need to correct for the selection arising from the likelihood of foreign entry. A positive estimated coefficient would indicate a higher liklihood of SS while a negative coefficient would indicate a tendency in favour of JV.

The corrected estimates of the complete model are summarised in columns (1) - (4) of Table 7: while columns (1)-(2) show the estimates for FO_SS, those in (3)-(4) show those for FO, respectively using ICRG and TI indices. In each case we use the final specification as shown in column (5) of Table 6. First, we find that all the estimated coefficients of various corruption quartiles are negative, but only the estimated Q3 coefficients are negative and significant for both FO specifications. Thus, the likelihood of foreign SS is lower when host corruption is at Q3 level, thus suggesting that the corresponding probability of JV is higher at Q3 level of corruption. Second we consider the differential effects of corruption when there is home-host institutional familiarity. In this respect, we find that the likelihood of SS is significantly higher for both Q2 and Q3 levels of corruption when the relative distance in home-host corruption levels is small (i.e., similar corruption levels in home and host countries). Finally, we consider the premium for home-host match in EU/OECD membership. Clearly, the dummy for both_eu_oecd is positive and significant, thus suggesting that the likelihood of SS increases significantly when both host and home countries are members of EU or OECD. Further all the interaction terms of both eu oecd with the corruption quartiles are positive, but none of them being statistically significant. As such, there is some confirmation that the level of corruption does not matter much when both home-host countries are members of EU/OECD. Further, we find that these results are not sensitive to the choice of corruption measures, ICRG or TI. Also the corresponding ordered probit estimates of FO shown in columns (3)-(4) are rather similar.

As such, there are similarities and differences in our results from Javorcik and Wei (2009) who found that the likelihood of JV is higher in corrupt host countries, except in the case of technically sofisticated firms. We find that, ceteris paribus, Q3 corruption is associated with lower likelihood of SS and therefore higher likelihood of JV. Also our estimates control for sector fixed effects and as such these estimates refer to within sector variation; we were unable to find any sector-specific effect for technologically sofisticated firms as in Javorcik and Wei (2009). Following Szulanski (1996), we argue that the additional costs of leakage associated with JV may not only be pertinent for technologically sofisticated firms but also for firms in other sectors, involving inter-organisational knowledge transfer with respect to both technology and management (see discussion in the introduction). Further, we show that the strength of this relationship between corruption and mode of entry may be 
weakened when one takes account of the networking arguments, which enhance the likelihood of SS at low to moderate levels of corruption, thus highlighting the value added of our results. Finally, the underlying cause of most joint ventures pertain to a desire among partners to access and/or pool markets, capital, technologies and/or skills (Miller et al. 1997). The fact that each party wants something the other party has, means that each will want different things from JV and the need may change quickly over time. As such, the perceived value of a local partner may decline over time as the foreign partner learns more about their host country operations. In other words, costs of JV may increase over time while that of SS may decline as the foreign owner gains experience. Accordingly, an analaysis of JV and SS may be captured better in a pooled/panel data-set rather than in a single cross-section data (e.g., that analysed by Javorcik and Wei (2009)). Further, unlike SS, a successful collaboration in JV may require discarding old ideas and practices (Szulanski, 1996), which may cause some stickiness in the inter-organisational knowledge transfer with respect to both technology and management. Taken together, the value attached to SS may be higher than that for JV over a period of time and this effect is likely to be stronger when the foreign investor is familiar with the institutions in the host country (either because of low home-host corruption distance and/or EU/OECD membership rules). This is what is borne out in our data, thus adding value to the literature.

\section{Conclusions}

Despite corruption and governance concerns in corrupt host economies, no one can deny that a large amount of FDI flows to countries with high corruption and imperfect governance including those in Asia, Africa, Europe and Latin America. In this context, we re-examine the relationship beween corruption and foreign entry and foreign ownership in a sample of CEE host countries and identify a possible non-linear relationship, if any, beween host corruption and foreign ownership in a sample of CEE countries. It is argued here that returns may exceed the costs of foreign investment at low to medium level of corrution and as such corruption may not deter foreign entry/ownership. However at a high level of corruption, costs may exceed or exactly outweigh the returns, thus giving rise to a negative or even an insignificant relationship between corruption and foreign ownership. Further, we hypothesize that a possible reason for this non-linearity may be linked to strategies adopted by foreign multinationals, e.g., investing in more familiar environment (e.g., choosing host countries with similar level of corruption as theirs and/or formal networking with EU/OECD countries) in a bid to minimise the costs of foreign investment in an unfamiliar host environment.

Results using a large home-host matched panel data from a group of CEE host countries over 2002-08 appear to provide some support to our central hypotheses. We use Wooldrige (1995) selectivity corrected panel fixed effects estimates of foreign ownership to minimise the firm-specific omitted variable 
bias after correcting for the selectivity bias arising from foreign entry decision . First, we find that any level of corruption may not necessarily harm foreign entry and/or size of foreign ownership in our sample though the favourable effect of corruption may disappear when corruption is too high. In particular, after correcting for the selectivity bias, we find that Q2 and Q3 levels of corruption are associated with higher foreign ownership though the relationship loses its significance at Q4 level of corruption. We next examine the validity of the networking hypothesis and find some support in our sample. In particular, there is suggestion that Q2 and Q3 levels of host corruption are associated with significantly higher foreign ownership when the home-host corruption distance is small and also when foreign multinationals from EU/OECD countries invest in EU/OECD host countries in the region. When we compare our results with those of Javorcik and Wei (2009), we find that Q3 level of corruption is associated with lower likelihood of SS, thus favouring JV for firms within a sector. However, we were unable to detect a differential effect for technologically sofisticated firms in our sample. The latter can be atributed to the fact that costs of JV may not only petain to technology transfer, but also to transfer of management strategy which may not be concentrated in one sector only. Further, ceteris paribus, the likelihood of SS increases at low to moderate levels of corruption, when the home-host corruption distance is low and also when there is home-host match in EU/OECD membership. We also argue that the strength of the corrupton-mode of foreign entry relationship would be higher when one has data over a period of time, thus adding further value to our analysis.

It is often argued that openness and globalisation may reduce corrupt domestic practices (Sung and Chu, 2003; Dahlstrom, 2012). Our results however highlight how parent firms may adopt alternative mechanisms to minimise the potential investment risks in more corrupt host environment, thus questioning the view whether globalization may necessarily lower the level of host corruption. While this is a study of the CEE region, it would be interesting to replicate our study for the countries beyond the region defined by our sample boundaries. We hope future research will address this.

\section{References}

1. Ayyagari, Meghana, Asli Demirguc-kunt and Vojislav Maksimovic, (forthcoming), Formal versus informal finance: Evidence from China, Review of financial studies.

2. Bardhan Pranab. 1997. 'Corruption and Development: A Review of Issues.' Journal of Economic Literature Vol. XXXV (September): 13201346.

3. Bevan, A. and S. Estrin. 2004. 'The determinants of foreign direct investment into European transition economies', Journal of Comparative Economics 32(4): 775-787.

4. Boisot, M. and Child, J., 1996. 'From Fiefs to Clans and Network Capitalism: Explaining China's Emerging Economic Order' Administrative 
Science Quarterly 41: 600-628.

5. Boycko, Maxim, Shleifer, Andrei, and Vishny, Robert, Privatizing Russia, Cambridge, MIT Press, 1995.

6. Budd, J.W., J. Konings, and M.J. Slaughter. 2005. 'Wages and International Rent Sharing in Multinational Firms. Review of Economics and Statistics 87 (1): 73-84.

7. Cuervo-Cazurra, A. 2008. 'The Effectiveness of Laws against Bribery Abroad', Journal of International Business Studies 39: 634-651.

8. Dahlstr'm, T. 2012. Globalisation and corruption Learning how to become less corrupt' mimeo, University of Nottingham, UK.

9. Egger, P. and H. Winner. 2005. 'Evidence on corruption as an incentive for foreign direct investment', European Journal of Political Economy 21: 932-952.

10. Eicher, Theo S. and Schreiber, Till, 2010. 'Structural policies and growth: Time series evidence from a natural experiment', Journal of Development Economics 91(1): 196-179.

11. Globerman, S. and D. Shapiro. 200). 'Governance infrastructure and US foreign direct investment', Journal of International Business Studies, 34: 19-39.

12. Gomes-Casseres, B. 1987. 'Joint Venture Instability: Is It A Problem? Columbia Journal of World Business: 97-102.

13. Grief, Avner. 2006. Institutions and the Path to the Modern Economy. New York: Cambridge University Press.

14. Guiso, Luigi, Sapienza, Paola and Zingales, Luigi. 2004. 'The Role of Social Capital in Financial Development', American Economic Review 94: $526-566$.

15. Habib, Mohsin and Zurawicki, Leon. 2002. 'Corruption and foreign direct investment', Journal of International Business Studies 33(2): 291-307.

16. Heckman, J. 1979. 'Sample Selection Bias as a Specification Error', Econometrica 47(1): 153-161.

17. Helpman, E. 1993. 'Innovation, imitation and intellectual property rights', Econometrica 61: 1247-1280.

18. Helpman, E., M.J. Melitz, and S.R. Yeaple. 2004. 'Export versus FDI with Heterogeneous Firm', American Economic Review, 94 (1): 300-316.

19. Henisz, W. 2000. 'The Institutional Environment for Multinational Investment', Journal of Law, Economics and Organisation 16: 334-364. 
20. Hines, J. R. Jr. 1995. 'Forbidden Payment: Foreign Bribery and American Business After 1977', NBER Working Paper 5266.

21. Javorcik, B.S. 2004. 'The Composition of Foreign Direct Investment and Protection of Intellectual Property Rights: Evidence from Transition Economies', European Economic Review, 48(1): 39- 62.

22. Javorcik, B.S. and S.J. Wei. 2009. 'Corruption and Cross-border Investment in Emerging Markets: Firm-Level Evidence', Journal of International Money and Finance, 28: 605-624.

23. Kandori M., 1992. 'Social norms and community enforcement', Review of Economic Studies 59 (1): 63-80.

24. Kaufman, D. and S. Wei. 1999. 'Does 'Grease Payment' Speed Up the Wheels of Commerce?', NBER Working Paper 7093.

25. Kaufman, D., A. Kraay and M. Mastruzzi. 2009. 'Governance Matters VIII. Aggregate and Individual Governance Indicators 1996-2008', Policy Research Working Paper 4978, World Bank.

26. Konings, J., and A. Murphy. 2006. 'Do Multinational Enterprises Relocate Employment to Low-Wage Regions? Evidence from European Multinationals. Review of World Economics 142 (1): 1-20.

27. Miller, R. J. Glen, F. Jaspersen and Y. Karmokolias. 1997. Finance and Development, March.

28. Mlachila, Montfort and Misa Takebe. 2011. 'FDI from BRICs to LICs: Emerging growth driver?' Working paper no. WP/11/78, International Monetary Fund.

29. Morisset, J.P., Lumenga-Neso, O., 2002. Administrative Barriers to Foreign Investment in Developing Countries. World Bank Policy Research WP, vol. 2848 .

30. Murphy, K.M., Schleifer, A. and Vishny, R.W. 1991. 'The Allocation of Talent: Implications for Growth, The Quarterly Journal of Economic's,106(2), 503-530.

31. OECD. 2006. 'Steps taken by state parties to implement and enforce the convention on combating bribery of foreign public officials in international business transactions.' Paris: Organization for Economic Co-operation and Development. http://www.oecd.org/dataoecd/50/33/1827022.pdf.

32. OECD. 2007. Compilation of recommendations made in the phase 2 reports. Paris: Organization for Economic Co-operation and Development. http://www.oecd.org/dataoecd/51/45/37171905.pdf.

33. OECD. 2011. 'Convention on Combating Bribery of Foreign Public Officials in International Business Transactions', http://www.oecd.org/dataoecd/4/18/38028044.pdf 
34. Rose-Ackerman, S. 1999. 'Corruption and Government: Causes, Consequences, and Reform'. Cambridge University Press.

35. Pinto Ribeiro, S., S. Menghinello and K. D. Backer. 2010. 'The OECD ORBIS Database: Responding to the Need for Firm-Level Micro-Data in the OECD', OECD Statistics Working Papers, 2010/01, OECD Publishing. http://dx.doi.org/10.1787/5kmhds8mzj8w-en

36. Shleifer, A. and Vishny, R.W. 1993. Corruption, The Quarterly Journal of Economics,108(3): 599-617.

37. Sung, H-E, and Chu, D. 2003. 'Does participation in the global economy reduce political corruption?' International Journal of Comparative Criminology, 3(2): 94-' 118.

38. Szulanski, G. 1996. 'Exploring internal stickiness: Impediments to the transfer of best practices within the firm', Strategic Management Journal 17: $27-43$.

39. Tanzi and Davoodi . 2000 'Corruption, Growth and Public Finances', IMF working paper No. 116. Washington: International Monetary Fund.

40. Tsang, E. 'Organisational learning and unlearning: Transferring knowledge to greenfield vs. acquisition JV', mimeo Warwick.

41. Wei, S-J. 1997. ' How Taxing is Corruption on International Investors', No. 6030, NBER Working Papers.

42. Wei, S-J. 2000. 'How Taxing Is Corruption on International Investors?', Review of Economics and Statistics, 82(1): 1-11.

43. Wooldridge, J.M. 1995. 'Selection corrections for panel data models under conditional mean independence assumptions', Journal of Econometrics, 68(1):115-132. 
Table 1. Distribution of host firms and countries in the sample (2002-2008)

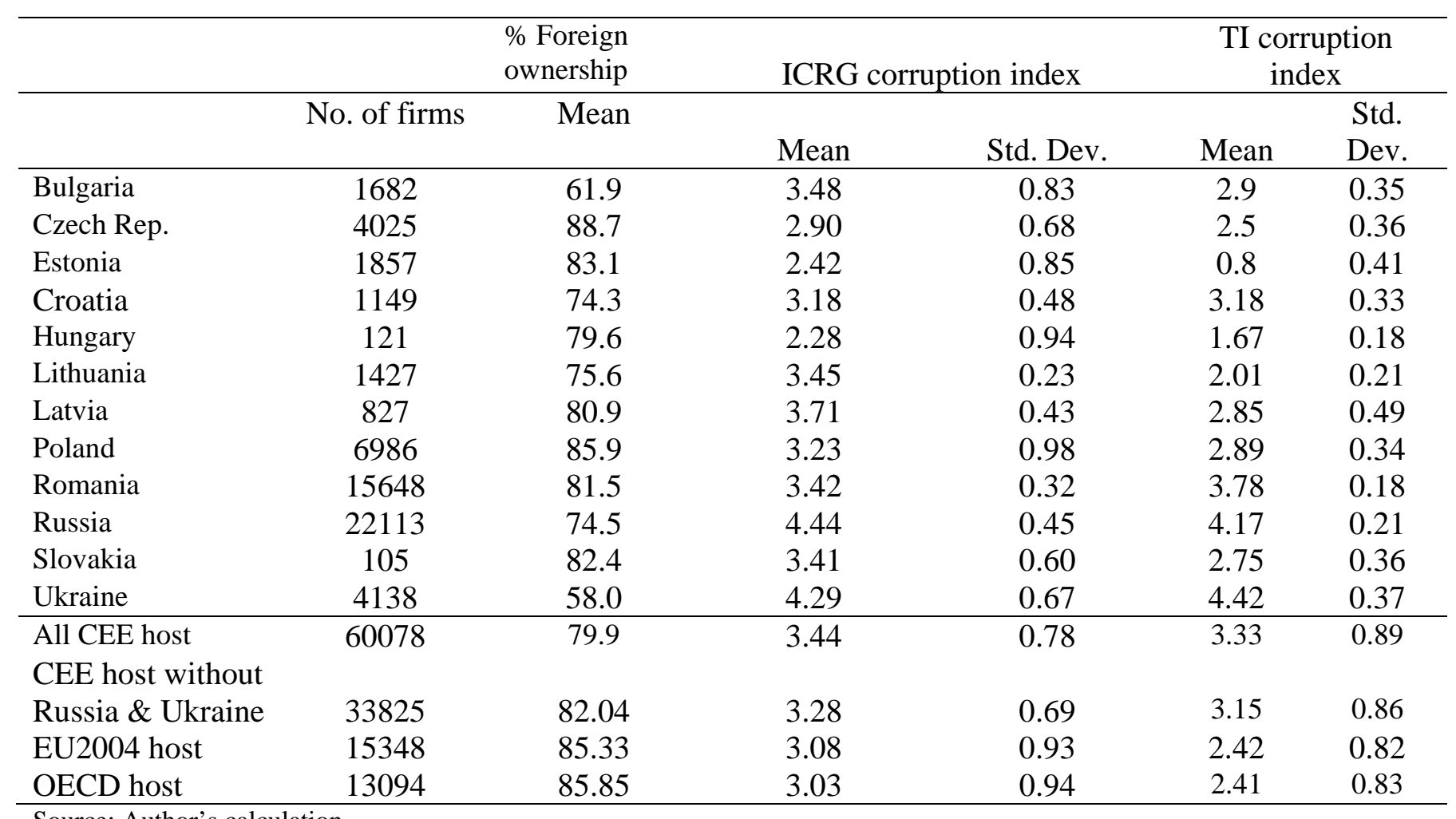


Table 2. Summary Statistics of regression variables, matched sample

\begin{tabular}{|c|c|c|c|c|c|c|}
\hline \multicolumn{7}{|c|}{ Std. } \\
\hline Variable & & Mean & Dev. & Min & Max & Observations \\
\hline \multirow[t]{3}{*}{ \%foreign ownership } & overall & 12.84392 & 31.68928 & 0 & 100 & $\mathrm{~N}=328808$ \\
\hline & between & & 31.19861 & 0 & 100 & $\mathrm{n}=60073$ \\
\hline & within & & 1.939275 & -69.6561 & 81.40106 & $\mathrm{~T}$-bar $=5.47347$ \\
\hline \multicolumn{7}{|l|}{ \%foreign ownership } \\
\hline \multirow[t]{3}{*}{$>0$} & overall & 80.49526 & 29.11978 & 0.01 & 100 & $N=52465$ \\
\hline & between & & 28.14651 & 0.01 & 100 & $\mathrm{n}=9079$ \\
\hline & within & & 4.854888 & -2.00474 & 149.0524 & T-bar $=5.77872$ \\
\hline \multirow[t]{3}{*}{ Host corruption } & overall & 3.888309 & 0.690529 & 1 & 5 & $\mathrm{~N}=328808$ \\
\hline & between & & 0.535104 & 1.861111 & 5 & $\mathrm{n}=60073$ \\
\hline & within & & 0.401839 & 2.269261 & 5.027198 & T-bar $=5.47347$ \\
\hline \multirow[t]{3}{*}{ Host corruption Q2 } & overall & 0.290899 & 0.454178 & 0 & 1 & $N=328808$ \\
\hline & between & & 0.335651 & 0 & 1 & $\mathrm{n}=60073$ \\
\hline & within & & 0.334892 & -0.54243 & 1.148042 & $\mathrm{~T}$-bar $=5.47347$ \\
\hline \multirow[t]{3}{*}{ Host corruption Q3 } & overall & 0.247196 & 0.431382 & 0 & 1 & $N=328808$ \\
\hline & between & & 0.263687 & 0 & 1 & $\mathrm{n}=60073$ \\
\hline & within & & 0.369746 & -0.60995 & 1.104339 & $\mathrm{~T}$-bar $=5.47347$ \\
\hline \multirow[t]{3}{*}{ host corruption Q4 } & overall & 0.290924 & 0.454189 & 0 & 1 & $N=328808$ \\
\hline & between & & 0.360465 & 0 & 1 & $\mathrm{n}=60073$ \\
\hline & within & & 0.275207 & -0.54241 & 0.9575902 & $\mathrm{~T}$-bar $=5.47347$ \\
\hline \multirow[t]{3}{*}{ Common border } & overall & 0.146316 & 0.353426 & 0 & 1 & $\mathrm{~N}=53200$ \\
\hline & between & & 0.349441 & 0 & 1 & $\mathrm{n}=9219$ \\
\hline & within & & 0.053868 & -0.71083 & 1.003459 & T-bar $=5.77069$ \\
\hline lag_host_medium & overall & 0.502531 & 0.499995 & 0 & 1 & $N=281113$ \\
\hline
\end{tabular}




\begin{tabular}{|c|c|c|c|c|c|c|}
\hline & between & & 0.424172 & 0 & 1 & $\mathrm{n}=58533$ \\
\hline & within & & 0.281764 & -0.35461 & 1.359674 & T-bar $=4.80264$ \\
\hline \multirow[t]{3}{*}{ lag_host_large } & overall & 0.239167 & 0.426576 & 0 & 1 & $\mathrm{~N}=281113$ \\
\hline & between & & 0.372419 & 0 & 1 & $\mathrm{n}=58533$ \\
\hline & within & & 0.179138 & -0.61798 & 1.09631 & $\mathrm{~T}-\mathrm{bar}=4.80264$ \\
\hline \multirow[t]{3}{*}{ lag_log_tfp } & overall & 2.211772 & 0.731761 & -10.502 & 10.29765 & $N=216421$ \\
\hline & between & & 0.667728 & -6.04512 & 8.443387 & $\mathrm{n}=54790$ \\
\hline & within & & 0.324238 & -6.49345 & 8.541178 & $\mathrm{~T}$-bar $=3.95001$ \\
\hline \multirow[t]{3}{*}{ lag_Host_IATA } & overall & 0.006011 & 0.255539 & 0 & 134.0892 & $\mathrm{~N}=280569$ \\
\hline & between & & 0.115811 & 0 & 27.0742 & $\mathrm{n}=58467$ \\
\hline & within & & 0.227145 & -27.068 & 107.021 & $\mathrm{~T}$-bar $=4.79876$ \\
\hline \multirow[t]{3}{*}{ lag_log_mkt_sh } & overall & -9.68978 & 2.177073 & -25.6957 & -0.6198877 & $N=273083$ \\
\hline & between & & 2.096837 & -22.4568 & -1.464571 & $\mathrm{n}=57970$ \\
\hline & within & & 0.683028 & -21.7317 & -2.885721 & T-bar $=4.71076$ \\
\hline \multirow[t]{3}{*}{ lag_home_medium } & overall & 0.493979 & 0.499986 & 0 & 1 & $N=11377$ \\
\hline & between & & 0.474262 & 0 & 1 & $n=2614$ \\
\hline & within & & 0.171956 & -0.36316 & 1.351122 & $\mathrm{~T}$-bar $=4.35233$ \\
\hline \multirow[t]{3}{*}{ lag_home_large } & overall & 0.254988 & 0.435874 & 0 & 1 & $N=11377$ \\
\hline & between & & 0.387292 & 0 & 1 & $\mathrm{n}=2614$ \\
\hline & within & & 0.114135 & -0.60215 & 1.112131 & $\mathrm{~T}$-bar $=4.35233$ \\
\hline \multirow[t]{3}{*}{ home_IATA } & overall & 0.107787 & 0.182848 & -1.90138 & 1 & $N=12824$ \\
\hline & between & & 0.168449 & -0.47534 & 1 & $n=2734$ \\
\hline & within & & 0.06166 & -1.31824 & 0.8577872 & $\mathrm{~T}$-bar $=4.69056$ \\
\hline \multirow[t]{3}{*}{$\begin{array}{l}\text { Infrastructural } \\
\text { index }\end{array}$} & overall & 2.838331 & 0.431325 & 2 & 3.7 & $N=328808$ \\
\hline & between & & 0.396976 & 2 & 3.7 & $\mathrm{n}=60073$ \\
\hline & within & & 0.142912 & 2.124046 & 3.338331 & $\mathrm{~T}$-bar $=5.47347$ \\
\hline \multirow[t]{2}{*}{ Openness } & overall & 81.95255 & 28.01648 & 54.82 & 174.4 & $N=328808$ \\
\hline & between & & 28.01838 & 54.82 & 173.34 & $\mathrm{n}=60073$ \\
\hline
\end{tabular}




\begin{tabular}{|c|c|c|c|c|c|c|}
\hline \multirow{4}{*}{ Competition policy } & within & & 5.570638 & 65.50588 & 104.9397 & $\mathrm{~T}$-bar $=5.47347$ \\
\hline & overall & 2.517984 & 0.324944 & 2.33 & 3.67 & $N=328808$ \\
\hline & between & & 0.318146 & 2.33 & 3.67 & $\mathrm{n}=60073$ \\
\hline & within & & 0.115854 & 2.045127 & 3.045127 & $\mathrm{~T}$-bar $=5.47347$ \\
\hline
\end{tabular}

Source: Author's calculation using the sample.

All monetary values are deflated and expressed in thousands of US dollars.

Common border is a dummy that takes a value 1 if home country is bordering the host country; it is 0 otherwise.

Openness is measured by the sum of exports and imports as a share of GDP ratio; source: World Development Indicators

EBRD infrastructure index

EBRD competition policy index 
Table 3. Wooldridge first stage using ICRG Index: Probit estimates of likelihood of foreign entry

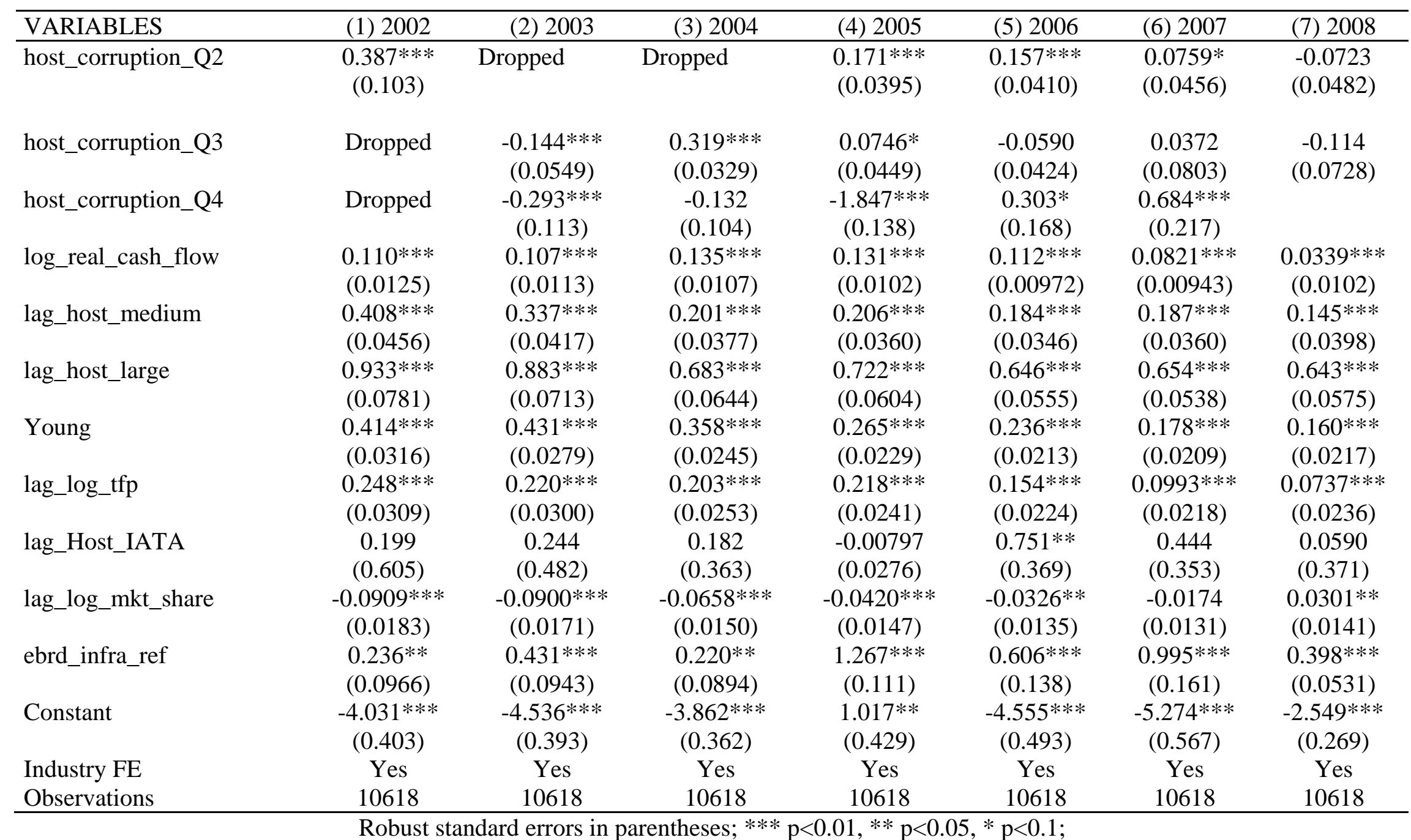


Table 4. Uncorrected and Wooldridge Corrected FE estimates of \% Foreign Ownership

\begin{tabular}{|c|c|c|c|c|}
\hline \multirow[b]{3}{*}{ VARIABLES } & \multirow{2}{*}{\multicolumn{2}{|c|}{$\begin{array}{lc}(1) & (2) \\
\text { Using ICRG corruption index }\end{array}$}} & \multirow{2}{*}{\multicolumn{2}{|c|}{$\begin{array}{l}(3) \\
\text { Using TI corruption index }\end{array}$}} \\
\hline & & & & \\
\hline & Uncorrected & Corrected ICRG & Uncorrected & Corrected ICRG \\
\hline host_corruption_Q2 & $\begin{array}{l}1.799 * \\
(1.074)\end{array}$ & $\begin{array}{l}2.262 * \\
(1.307)\end{array}$ & $\begin{array}{l}1.944^{*} \\
(1.008)\end{array}$ & $\begin{array}{l}2.355^{*} \\
(1.211)\end{array}$ \\
\hline host_corruption_Q3 & $\begin{array}{c}1.618 \\
(1.233)\end{array}$ & $\begin{array}{l}1.811^{*} \\
(1.067)\end{array}$ & $\begin{array}{l}1.423 \\
(1.267)\end{array}$ & $\begin{array}{l}1.227 \\
(1.496)\end{array}$ \\
\hline host_corruption_Q4 & $\begin{array}{l}7.485^{*} \\
(4.252)\end{array}$ & $\begin{array}{l}9.558 \\
(5.969)\end{array}$ & $\begin{array}{l}7.384 * \\
(4.251)\end{array}$ & $\begin{array}{c}9.330 \\
(5.955)\end{array}$ \\
\hline lag_host_medium & $\begin{array}{c}2.784 \\
(2.240)\end{array}$ & $\begin{array}{c}1.333 \\
(2.746)\end{array}$ & $\begin{array}{c}2.885 \\
(2.241)\end{array}$ & $\begin{array}{c}1.689 \\
(2.741)\end{array}$ \\
\hline lag_host_large & $\begin{array}{l}1.186 \\
(2.621)\end{array}$ & $\begin{array}{l}-3.067 \\
(3.274)\end{array}$ & $\begin{array}{l}1.462 \\
(2.625)\end{array}$ & $\begin{array}{l}-2.311 \\
(3.271)\end{array}$ \\
\hline Young & $\begin{array}{l}0.575 \\
(1.492)\end{array}$ & $\begin{array}{l}-0.783 \\
(1.696)\end{array}$ & $\begin{array}{c}0.595 \\
(1.491)\end{array}$ & $\begin{array}{l}-0.571 \\
(1.693)\end{array}$ \\
\hline lag_log_tfp & $\begin{array}{l}-0.484 \\
(0.913)\end{array}$ & $\begin{array}{c}0.756 \\
(1.116)\end{array}$ & $\begin{array}{c}-0.454 \\
(0.915)\end{array}$ & $\begin{array}{c}0.996 \\
(1.113)\end{array}$ \\
\hline lag_Host_IATA & $\begin{array}{l}4.536 \\
(12.54)\end{array}$ & $\begin{array}{c}4.504 \\
(14.90)\end{array}$ & $\begin{array}{l}4.645 \\
(12.42)\end{array}$ & $\begin{array}{c}4.813 \\
(14.72)\end{array}$ \\
\hline lag_log_mkt_share & $\begin{array}{c}1.457 * * * \\
(0.526)\end{array}$ & $\begin{array}{l}1.426 * * \\
(0.624)\end{array}$ & $\begin{array}{c}1.407 * * * \\
(0.526)\end{array}$ & $\begin{array}{l}1.334^{* *} \\
(0.622)\end{array}$ \\
\hline lag_Parent_medium & $\begin{array}{c}4.877^{* * * *} \\
(0.838)\end{array}$ & $\begin{array}{c}4.912 * * * \\
(0.970)\end{array}$ & $\begin{array}{c}4.894^{* * * *} \\
(0.838)\end{array}$ & $\begin{array}{c}4.953 * * * \\
(0.969)\end{array}$ \\
\hline lag_Parent_large & $\begin{array}{c}3.914^{* * *} \\
(1.085)\end{array}$ & $\begin{array}{c}5.223^{* * *} \\
(1.251)\end{array}$ & $\begin{array}{c}3.928 * * * \\
(1.085)\end{array}$ & $\begin{array}{c}5.237 * * * \\
(1.250)\end{array}$ \\
\hline Parent_IATA & $\begin{array}{c}-3.642 * * \\
(1.582)\end{array}$ & $\begin{array}{c}-6.517 * * * \\
(1.932)\end{array}$ & $\begin{array}{c}-3.478 * * \\
(1.578)\end{array}$ & $\begin{array}{c}-6.321 * * * \\
(1.925)\end{array}$ \\
\hline EBRD_compet_pol & $4.372 * * *$ & $7.580 * * *$ & 1.688 & $3.549 *$ \\
\hline
\end{tabular}




\begin{tabular}{lcccc} 
Constant & $(1.588)$ & $(1.855)$ & $(1.815)$ & $(2.127)$ \\
& $75.84^{* * *}$ & $83.51^{* * *}$ & $82.65^{* * *}$ & $92.81^{* * *}$ \\
Lambda & $(5.671)$ & $(7.617)$ & $(6.115)$ & $(8.004)$ \\
& No & $-10.91^{* * *}$ & No & $-9.181^{* *}$ \\
Firm FE & & $(3.676)$ & Yes & $(3.625)$ \\
Year FE & Yes & Yes & Yes & Yes \\
Firm*year FE & Yes & Yes & Yes & Yes \\
Observations & Yes & Yes & 5467 & 5467 \\
R-squared & 5467 & 5467 & 0.036 & 0.048 \\
\hline \multicolumn{7}{c}{}
\end{tabular}
${ }^{* * *} \mathrm{p}<0.01,{ }^{* *} \mathrm{p}<0.05,{ }^{*} \mathrm{p}<0.1$ 
Table 5. Comparison of Panel FE model with alternative models

\begin{tabular}{|c|c|c|c|}
\hline & $\begin{array}{c}(1) \\
\text { Pooled } \\
\text { Tobit }\end{array}$ & $\begin{array}{c}(2) \\
\text { Pooled } \\
\text { Heckman } \\
2^{\text {nd }} \text { stage } \\
\end{array}$ & $\begin{array}{c}(3) \\
\text { Corrected } \\
\text { Panel FE } \\
\text { Wooldridge } \\
\end{array}$ \\
\hline VARIABLES & percentage_FO & $\begin{array}{c}\text { percentage_ } \\
\text { FO }\end{array}$ & percentage_FO \\
\hline host_corruption_Q2 & $\begin{array}{c}2.283 \\
(1.762)\end{array}$ & $\begin{array}{l}1.491^{*} \\
(0.768)\end{array}$ & $\begin{array}{c}2.665 * * \\
(1.310)\end{array}$ \\
\hline host_corruption_Q3 & $\begin{array}{c}-6.431 * * * \\
(1.972)\end{array}$ & $\begin{array}{c}-0.229 \\
(0.910)\end{array}$ & $\begin{array}{l}2.443^{*} \\
(1.487)\end{array}$ \\
\hline host_corruption_Q4 & $\begin{array}{c}-19.32 * * * \\
(4.684)\end{array}$ & $\begin{array}{l}-0.727 \\
(3.246)\end{array}$ & $\begin{array}{c}9.354 \\
(5.949)\end{array}$ \\
\hline Lambda_wooldridge & & & $\begin{array}{c}-10.15^{* * *} \\
(3.682)\end{array}$ \\
\hline lambda_heckman & & $\begin{array}{c}3.783 \\
(4.089)\end{array}$ & \\
\hline Constant & $\begin{array}{c}58.09 * * * \\
(10.43)\end{array}$ & $\begin{array}{c}39.44^{* * *} \\
(7.823)\end{array}$ & $\begin{array}{c}93.06^{* * * *} \\
(8.015)\end{array}$ \\
\hline Sigma & $\begin{array}{c}56.81^{* * *} \\
(0.844)\end{array}$ & & \\
\hline Other control variables & Yes & Yes & Yes \\
\hline Firm FE & No & No & Yes \\
\hline Year FE & No & No & Yes \\
\hline Firm*Year & No & No & Yes \\
\hline Observations & 9185 & 5475 & 5467 \\
\hline R-squared & & 0.066 & 0.048 \\
\hline
\end{tabular}


Table 6. Effects of networking: Corrected Wooldridge FE-estimates of Foreign Ownership

\begin{tabular}{|c|c|c|c|c|c|}
\hline VARIABLES & $\begin{array}{c}\text { (1) } \\
\text { Relative corruption }\end{array}$ & $\begin{array}{c}(2) \\
\text { EU-EU }\end{array}$ & $\begin{array}{c}\text { (3) } \\
\text { OECD-OECD }\end{array}$ & $\begin{array}{c}(4) \\
\text { EU/OECD }\end{array}$ & $\begin{array}{c}\text { (5) } \\
\text { Relative corruption } \\
\text { \& EU/OECD }\end{array}$ \\
\hline host_corruption_Q2 & $\begin{array}{l}1.275 \\
(1.439)\end{array}$ & $\begin{array}{l}3.575 * * \\
(1.677)\end{array}$ & $\begin{array}{c}2.669 \\
(1.650)\end{array}$ & $\begin{array}{l}4.040^{* *} \\
(1.828)\end{array}$ & $\begin{array}{l}1.818 \\
(2.111)\end{array}$ \\
\hline host_corruption_Q3 & $\begin{array}{c}0.146 \\
(1.607)\end{array}$ & $\begin{array}{c}0.842 \\
(2.085)\end{array}$ & $\begin{array}{c}0.103 \\
(2.001)\end{array}$ & $\begin{array}{c}0.274 \\
(2.408)\end{array}$ & $\begin{array}{l}-2.760 \\
(2.713)\end{array}$ \\
\hline host_corruption_Q4 & $\begin{array}{l}9.033^{*} \\
\text { (5.108) }\end{array}$ & $\begin{array}{l}9.919^{*} \\
(5.125)\end{array}$ & $\begin{array}{l}8.881^{*} \\
(5.067)\end{array}$ & $\begin{array}{l}9.268^{*} \\
(5.152)\end{array}$ & $\begin{array}{c}6.631 \\
(5.616)\end{array}$ \\
\hline rc_q1 & $\begin{array}{l}-1.959 \\
(1.739)\end{array}$ & & & & $\begin{array}{l}-2.080 \\
(1.789)\end{array}$ \\
\hline rc_q1*corruption_q2 & $\begin{array}{l}4.708^{* *} \\
(1.941)\end{array}$ & & & & $\begin{array}{l}4.826 * * \\
(2.032)\end{array}$ \\
\hline rc_q1*corruption_q3 & $\begin{array}{l}5.769 * * \\
(2.506)\end{array}$ & & & & $\begin{array}{c}7.956 * * * \\
(2.670)\end{array}$ \\
\hline rc_q1 $1 *$ corruption_q4 & $\begin{array}{c}3.523 \\
(6.856)\end{array}$ & & & & $\begin{array}{l}-0.513 \\
(7.982)\end{array}$ \\
\hline eu_eu & & $\begin{array}{c}9.959 * * * \\
(2.052)\end{array}$ & & & \\
\hline eu_eu*corruption_q2 & & $\begin{array}{l}-2.670 \\
(1.882)\end{array}$ & & & \\
\hline eu_eu*corruption_q3 & & $\begin{array}{c}0.455 \\
(2.412)\end{array}$ & & & \\
\hline eu_eu*corruption_q4 & & Dropped & & & \\
\hline oecd_oecd & & & $\begin{array}{l}-1.100 \\
(1.331)\end{array}$ & & \\
\hline oecd_oecd*corruption_q2 & & & $\begin{array}{l}0.0457 \\
(1.673)\end{array}$ & & \\
\hline
\end{tabular}


oecd_oecd*corruption_q3

oecd_oecd*corruption_q4

both_eu_oecd

both_eu_oecd*corruption_q2

both_eu_oecd*corruption_q3

both_eu_oecd*corruption_q4

Common border

both_eu_oecd*common border

\section{Lambda}

Constant

Firm FE

Year FE

Firm*year

Other Control variables

Observations

R-squared

\begin{tabular}{|c|c|c|c|c|}
\hline & & $\begin{array}{c}3.265 \\
(2.091) \\
\text { Dropped }\end{array}$ & & \\
\hline & & & $\begin{array}{c}8.221^{* * *} \\
(2.823) \\
-3.147 \\
(1.994) \\
0.929 \\
(2.806) \\
\text { Dropped }\end{array}$ & $\begin{array}{c}7.544 * * * \\
(2.873) \\
-1.816 \\
(2.090) \\
2.836 \\
(2.965) \\
\text { Dropped }\end{array}$ \\
\hline & & & $\begin{array}{c}\text { Dropped } \\
2.137^{* *} \\
(0.846)\end{array}$ & $\begin{array}{c}-5.418 \\
(3.569) \\
6.422 * * \\
(3.168)\end{array}$ \\
\hline $\begin{array}{c}-8.990 * * \\
(3.710)\end{array}$ & $\begin{array}{c}-6.626 * * * \\
(1.725)\end{array}$ & $\begin{array}{c}-10.90 * * * \\
(3.821)\end{array}$ & $\begin{array}{c}-9.606^{* *} \\
(3.834)\end{array}$ & $\begin{array}{c}-9.130 * * \\
(3.832)\end{array}$ \\
\hline $\begin{array}{c}87.79 * * * \\
(7.857)\end{array}$ & $\begin{array}{c}89.16^{* * *} \\
(7.585)\end{array}$ & $\begin{array}{c}82.17^{* * *} \\
(7.971)\end{array}$ & $\begin{array}{c}91.25^{* * *} \\
(8.352)\end{array}$ & $\begin{array}{c}90.73 * * * \\
(8.429)\end{array}$ \\
\hline Yes & Yes & Yes & Yes & Yes \\
\hline Yes & Yes & Yes & Yes & Yes \\
\hline Yes & Yes & Yes & Yes & Yes \\
\hline Yes & Yes & Yes & Yes & Yes \\
\hline 5467 & 5467 & 5467 & 5467 & 5467 \\
\hline 0.050 & 0.059 & 0.046 & 0.051 & 0.054 \\
\hline
\end{tabular}

Robust standard errors in parentheses; ${ }^{* * *} \mathrm{p}<0.01,{ }^{* *} \mathrm{p}<0.05,{ }^{*} \mathrm{p}<0.1$; other control variables are as in Table 4. 
Table 7. Effects of networking: Selectivity corrected estimates of sole foreign ownership (FO_SS and FO)

\begin{tabular}{|c|c|c|c|c|}
\hline VARIABLES & $\begin{array}{c}\text { (1) ICRG } \\
\text { FO_SS }\end{array}$ & $\begin{array}{c}\text { (2) TI } \\
\text { FO_SS }\end{array}$ & $\begin{array}{c}\text { (3) ICRG } \\
\text { FO } \\
\end{array}$ & $\begin{array}{c}\text { (4) TI } \\
\text { FO }\end{array}$ \\
\hline host_corruption_Q2 & $\begin{array}{l}-0.0152 \\
(0.123)\end{array}$ & & $\begin{array}{c}-0.0603 \\
(0.117)\end{array}$ & \\
\hline host_corruption_Q3 & $\begin{array}{c}-0.395 * * * \\
(0.129)\end{array}$ & & $\begin{array}{c}-0.322 * * * \\
(0.121)\end{array}$ & \\
\hline host_corruption_Q4 & $\begin{array}{l}-0.245 \\
(0.197)\end{array}$ & & $\begin{array}{c}-0.0611 \\
(0.171)\end{array}$ & \\
\hline host_corruption_Q2_TI & & $\begin{array}{c}-0.0397 \\
(0.119)\end{array}$ & & $\begin{array}{l}-0.0657 \\
(0.114)\end{array}$ \\
\hline host_corruption_Q3_TI & & $\begin{array}{c}-0.412 * * * \\
(0.128)\end{array}$ & & $\begin{array}{c}-0.322 * * * \\
(0.121)\end{array}$ \\
\hline host_corruption_Q4_TI & & $\begin{array}{l}-0.267 \\
(0.195)\end{array}$ & & $\begin{array}{c}-0.0668 \\
(0.170)\end{array}$ \\
\hline rc_q1 & $\begin{array}{l}-0.184^{*} \\
(0.0979)\end{array}$ & $\begin{array}{c}-0.215^{* *} \\
(0.103)\end{array}$ & $\begin{array}{c}-0.243^{* * *} \\
(0.0897)\end{array}$ & $\begin{array}{c}-0.253^{* * * *} \\
(0.0957)\end{array}$ \\
\hline rc_q1*corruption_Q2 & $\begin{array}{l}0.224^{*} \\
(0.119)\end{array}$ & & $\begin{array}{c}0.228 * * \\
(0.107)\end{array}$ & \\
\hline rc_q1*corruption_Q3 & $\begin{array}{c}0.417^{* *} \\
(0.162)\end{array}$ & & $\begin{array}{l}0.259^{*} \\
(0.141)\end{array}$ & \\
\hline rc_q1*corruption_Q4 & $\begin{array}{l}0.0556 \\
(0.580)\end{array}$ & & $\begin{array}{c}0.527 \\
(0.391)\end{array}$ & \\
\hline rc_q1*corruptionQ2_TI & & $\begin{array}{c}0.257 * * \\
(0.122)\end{array}$ & & $\begin{array}{c}0.231^{* *} \\
(0.111)\end{array}$ \\
\hline rc_q1*corruptionQ3_TI & & $\begin{array}{c}0.448 * * * \\
(0.165)\end{array}$ & & $\begin{array}{l}0.270^{*} \\
(0.144)\end{array}$ \\
\hline rc_q1*corruptionQ4_TI & & 0.0820 & & 0.531 \\
\hline
\end{tabular}




$\begin{array}{lcccc}\text { Other firm controls } & \text { Yes } & \text { Yes } & \text { Yes } & \text { Yes } \\ \text { Year control } & \text { Yes } & \text { Yes } & \text { Yes } & \text { Yes } \\ \text { Sector control } & \text { Yes } & \text { Yes } & \text { Yes } & \text { Yes } \\ \text { Observations } & 5455 & 5455 & 5467 & 5467\end{array}$

Robust standard errors in parentheses; ${ }^{* * *} \mathrm{p}<0.01,{ }^{* *} \mathrm{p}<0.05,{ }^{*} \mathrm{p}<0.1$; other firm-level control variables are as in Table 4.

FO_SS=1 if foreign ownership $>=90 \%$ and 0 otherwise; FO= 3 if $100 \%$ foreign ownership; FO =2 if majority foreign ownership (51-99.99); FO=1 if minority foreign ownership (10-50.99) and FO=0 if foreign ownership 1-10\%. 


\section{Appendix Table A1. Wooldridge first stage using CPI: Probit estimates of likelihood of foreign entry}

\begin{tabular}{|c|c|c|c|c|c|c|c|}
\hline VARIABLES & (1)2002 & (2)2003 & (3)2004 & (4)2005 & (5)2006 & (6)2007 & (7)2008 \\
\hline host_corruption_Q2_TI & $\begin{array}{c}0.387^{* * *} \\
(0.102)\end{array}$ & $\begin{array}{l}0.406 * * * \\
(0.0617)\end{array}$ & Dropped & $\begin{array}{c}0.171^{* * *} \\
(0.0399)\end{array}$ & $\begin{array}{c}0.157 * * * \\
(0.0422)\end{array}$ & $\begin{array}{l}0.0759 * \\
(0.0449)\end{array}$ & $\begin{array}{l}0.0723^{*} \\
(0.0425)\end{array}$ \\
\hline host_corruption_Q3_TI & Dropped & $\begin{array}{c}-0.180 * * * \\
(0.0558)\end{array}$ & $\begin{array}{c}0.319 * * * \\
(0.0331)\end{array}$ & $\begin{array}{l}0.0746 * \\
(0.0404)\end{array}$ & $\begin{array}{l}0.303^{*} \\
(0.165)\end{array}$ & $\begin{array}{c}0.0780 * * \\
(0.0372)\end{array}$ & $\begin{array}{c}-0.114 \\
(0.0711)\end{array}$ \\
\hline host_corruption_Q4_TI & Dropped & $\begin{array}{l}0.0686 \\
(0.119)\end{array}$ & $\begin{array}{l}-0.132 \\
(0.101)\end{array}$ & $\begin{array}{c}-1.847 * * * \\
(0.129)\end{array}$ & $\begin{array}{l}-0.0590 \\
(0.0427)\end{array}$ & $\begin{array}{c}0.684^{* * *} \\
(0.208)\end{array}$ & Dropped \\
\hline log_real_cash_flow & $\begin{array}{c}0.110^{* * *} \\
(0.0137)\end{array}$ & $\begin{array}{c}0.108 * * * \\
(0.0126)\end{array}$ & $\begin{array}{c}0.135^{* * *} \\
(0.0117)\end{array}$ & $\begin{array}{c}0.131^{* * *} \\
(0.0111)\end{array}$ & $\begin{array}{c}0.112 * * * \\
(0.0103)\end{array}$ & $\begin{array}{c}0.0821^{* * *} \\
(0.0103)\end{array}$ & $\begin{array}{c}0.0339 * * * \\
(0.0108)\end{array}$ \\
\hline lag_host_medium & $\begin{array}{c}0.408 * * * \\
(0.0471)\end{array}$ & $\begin{array}{c}0.338 * * * \\
(0.0428)\end{array}$ & $\begin{array}{c}0.201 * * * \\
(0.0383)\end{array}$ & $\begin{array}{c}0.206 * * * \\
(0.0369)\end{array}$ & $\begin{array}{c}0.184 * * * \\
(0.0354)\end{array}$ & $\begin{array}{c}0.187 * * * \\
(0.0370)\end{array}$ & $\begin{array}{c}0.145 * * * \\
(0.0405)\end{array}$ \\
\hline lag_host_large & $\begin{array}{c}0.933^{* * * *} \\
(0.0792)\end{array}$ & $\begin{array}{l}0.953 * * * \\
(0.0726)\end{array}$ & $\begin{array}{c}0.683 * * * \\
(0.0643)\end{array}$ & $\begin{array}{l}0.722 * * * \\
(0.0611)\end{array}$ & $\begin{array}{c}0.646 * * * \\
(0.0560)\end{array}$ & $\begin{array}{c}0.654 * * * \\
(0.0540)\end{array}$ & $\begin{array}{c}0.643^{* * *} \\
(0.0569)\end{array}$ \\
\hline young & $\begin{array}{c}0.414 * * * \\
(0.0315)\end{array}$ & $\begin{array}{c}0.422 * * * \\
(0.0281)\end{array}$ & $\begin{array}{c}0.358 * * * \\
(0.0247)\end{array}$ & $\begin{array}{c}0.265^{* * *} \\
(0.0229)\end{array}$ & $\begin{array}{c}0.236 * * * \\
(0.0212)\end{array}$ & $\begin{array}{c}0.178^{* * *} \\
(0.0208)\end{array}$ & $\begin{array}{c}0.160 * * * \\
(0.0216)\end{array}$ \\
\hline lag_log_tfp & $\begin{array}{c}0.248 * * * \\
(0.0337)\end{array}$ & $\begin{array}{c}0.232 * * * \\
(0.0341)\end{array}$ & $\begin{array}{c}0.203^{* * *} \\
(0.0259)\end{array}$ & $\begin{array}{c}0.218 * * * \\
(0.0243)\end{array}$ & $\begin{array}{c}0.154 * * * \\
(0.0228)\end{array}$ & $\begin{array}{c}0.0993 * * * \\
(0.0247)\end{array}$ & $\begin{array}{c}0.0737 * * * \\
(0.0240)\end{array}$ \\
\hline lag_Host_IATA & $\begin{array}{c}0.199 \\
(0.531)\end{array}$ & $\begin{array}{c}0.539 \\
(0.498)\end{array}$ & $\begin{array}{c}0.182 \\
(0.388)\end{array}$ & $\begin{array}{c}-0.00797 * * \\
(0.00391)\end{array}$ & $\begin{array}{l}0.751^{*} \\
(0.388)\end{array}$ & $\begin{array}{c}0.444 \\
(0.358)\end{array}$ & $\begin{array}{l}0.0590 \\
(0.364)\end{array}$ \\
\hline lag_log_mkt_share & $\begin{array}{c}-0.0909 * * * \\
(0.0189)\end{array}$ & $\begin{array}{c}-0.0855 * * * \\
(0.0177)\end{array}$ & $\begin{array}{c}-0.0658 * * * \\
(0.0155)\end{array}$ & $\begin{array}{c}-0.0420 * * * \\
(0.0151)\end{array}$ & $\begin{array}{c}-0.0326^{* *} \\
(0.0140)\end{array}$ & $\begin{array}{l}-0.0174 \\
(0.0137)\end{array}$ & $\begin{array}{c}0.0301^{* *} \\
(0.0147)\end{array}$ \\
\hline ebrd_infra_ref & $\begin{array}{l}0.236 * * \\
(0.0955)\end{array}$ & $\begin{array}{c}0.856 * * * \\
(0.107)\end{array}$ & $\begin{array}{l}0.220 * * \\
(0.0895)\end{array}$ & $\begin{array}{c}-1.267 * * * \\
(0.107)\end{array}$ & $\begin{array}{c}0.606 * * * \\
(0.139)\end{array}$ & $\begin{array}{c}0.995^{* * * *} \\
(0.154)\end{array}$ & $\begin{array}{c}0.398 * * * \\
(0.0518)\end{array}$ \\
\hline Constant & $\begin{array}{c}-4.031 * * * \\
(0.404)\end{array}$ & $\begin{array}{c}-5.778 * * * \\
(0.418)\end{array}$ & $\begin{array}{c}-3.862 * * * \\
(0.361)\end{array}$ & $\begin{array}{c}1.017^{* *} \\
(0.415)\end{array}$ & $\begin{array}{c}-4.555 * * * \\
(0.496)\end{array}$ & $\begin{array}{c}-5.274 * * * \\
(0.553)\end{array}$ & $\begin{array}{c}-2.549 * * * \\
(0.271)\end{array}$ \\
\hline Sector control & Yes & Yes & Yes & Yes & Yes & Yes & Yes \\
\hline Observations & 10618 & 10618 & 10618 & 10618 & 10618 & 10618 & 10618 \\
\hline
\end{tabular}


Appendix Table A2. Wooldridge selectivity corrected panel FE estimates of percentage foreign ownership using TI corruption index

\begin{tabular}{|c|c|c|c|c|c|}
\hline VARIABLES & $\begin{array}{l}\text { (1) Relative } \\
\text { corruption }\end{array}$ & (2)EU_EU & (3)OECD_OECD & $\begin{array}{l}\text { (4) Both EU \& } \\
\text { OECD }\end{array}$ & (5) All arguments \\
\hline host_corruption_Q2_TI & $\begin{array}{l}1.835^{*} \\
(0.955)\end{array}$ & $\begin{array}{l}3.081 * * * \\
(0.908)\end{array}$ & $\begin{array}{l}3.113^{* *} \\
(1.380)\end{array}$ & $\begin{array}{l}5.339 * * * \\
(1.702)\end{array}$ & $\begin{array}{c}2.858 \\
(1.994)\end{array}$ \\
\hline host_corruption_Q3_TI & $\begin{array}{c}-0.638 \\
(1.158)\end{array}$ & $\begin{array}{l}0.0381 \\
(1.135)\end{array}$ & $\begin{array}{l}-1.842 \\
(1.770)\end{array}$ & $\begin{array}{l}-1.432 \\
(2.241)\end{array}$ & $\begin{array}{l}-4.340^{*} \\
(2.598)\end{array}$ \\
\hline host_corruption_Q4_TI & $\begin{array}{c}0.644 \\
(3.254)\end{array}$ & $\begin{array}{c}1.485 \\
(3.082)\end{array}$ & $\begin{array}{c}0.907 \\
(3.151)\end{array}$ & $\begin{array}{c}3.232 \\
(3.268)\end{array}$ & $\begin{array}{c}2.404 \\
(3.558)\end{array}$ \\
\hline rc_q1 & $\begin{array}{l}-2.029 \\
(1.780)\end{array}$ & & & & $\begin{array}{l}-1.955 \\
(1.908)\end{array}$ \\
\hline rc_q1_corruption Q2_TI & $\begin{array}{c}5.180 * * * \\
(1.952)\end{array}$ & & & & $\begin{array}{l}5.272 * * \\
(2.123)\end{array}$ \\
\hline rc_q1_corruptionQ3_TI & $\begin{array}{l}5.396^{* *} \\
(2.518)\end{array}$ & & & & $\begin{array}{c}8.578 * * * \\
(2.786)\end{array}$ \\
\hline rc_q1_corruptionQ4_TI & $\begin{array}{c}4.418 \\
(6.753)\end{array}$ & & & & $\begin{array}{c}7.889 \\
(7.014)\end{array}$ \\
\hline eu_eu & & $\begin{array}{l}3.647 \\
(2.734)\end{array}$ & & & \\
\hline eu_eu_corruptionQ2_TI & & $\begin{array}{l}-1.353 \\
(2.915)\end{array}$ & & & \\
\hline eu_eu_corruptionQ3_TI & & $\begin{array}{c}0.739 \\
(3.232)\end{array}$ & & & \\
\hline eu_eu_corruptionQ4_TI & & Dropped & & & \\
\hline
\end{tabular}


oecd_oecd_corruptionQ2_TI

oecd_oecd_corruptionQ3_TI

$3.720 *$

(2.111)

oecd_oecd_corruptionQ4_TI

Dropped

both_eu_oecd

both_eu_oecd_corruption Q2_TI

$\begin{array}{cc}7.578^{* * *} & 6.194^{* * *} \\ (2.130) & (2.229) \\ -2.358 & -1.175 \\ (1.925) & (2.090) \\ 2.953 & 5.035^{*} \\ (2.485) & (2.713) \\ \text { Dropped } & \text { Dropped }\end{array}$

both_eu_oecd_corruption Q4_TI

Dropped

Common_border

$-4.244$

(2.815)

Both_eu_oecd*Common border

Lambda

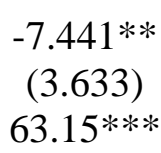

$-8.519 * *$

(3.613)

\section{Constant}

$63.15^{* * *}$

$65.39 * * *$

Firm FE

Year FE

Firm*Year FE

Other controls

Observations

(5.877)

Yes

(5.627)

Yes

Yes

Yes

Yes

Yes

5467

Yes

Yes

R-squared

$0.040 \quad 5467$

Robust standard errors in parentheses; ${ }^{* * *} \mathrm{p}<0.01,{ }^{* *} \mathrm{p}<0.05,{ }^{*} \mathrm{p}<0.1$; other control variables are as in Table 6 .

$-6.952 *$

(3.655)

$79.87 * * *$

$65.33^{* * *}$

(6.153)

Yes

Yes

Yes

Yes

5467

0.038

$-7.908 * *$

$81.21 * * *$

(7.230)

(7.384)

Yes

$\begin{array}{ll}\text { Yes } & \text { Yes } \\ \text { Yes } & \text { Yes }\end{array}$

$\begin{array}{ll}\text { Yes } & \text { Yes } \\ \text { Yes } & \text { Yes }\end{array}$

$5467 \quad 5467$

$0.043 \quad 0.048$ 
Table A3. Extended panel FE estimates of percentage foreign ownership (selectivity corrected)

\begin{tabular}{|c|c|c|}
\hline VARIABLES & (1) ICRG corruption & (2)TI corruption \\
\hline host_corruption_Q2 & $\begin{array}{c}2.379 \\
(2.028)\end{array}$ & \\
\hline host_corruption_Q3 & $\begin{array}{l}-4.321 * \\
(2.579)\end{array}$ & \\
\hline host_corruption_Q4 & $\begin{array}{c}1.337 \\
(3.603)\end{array}$ & \\
\hline host_corruption_Q2_TI & & $\begin{array}{c}1.807 \\
(2.045)\end{array}$ \\
\hline host_corruption_Q3_TI & & $\begin{array}{l}-4.740 * \\
(2.608)\end{array}$ \\
\hline host_corruption_Q4_TI & & $\begin{array}{c}0.674 \\
(3.616)\end{array}$ \\
\hline rc_q1 & $\begin{array}{c}-2.112 \\
(1.797)\end{array}$ & $\begin{array}{l}-2.658 \\
(1.964)\end{array}$ \\
\hline rc_q1_corruption_q2 & $\begin{array}{c}5.428 * * * \\
(2.032)\end{array}$ & \\
\hline rc_q1_corruption_q3 & $\begin{array}{c}8.434 * * * \\
(2.703)\end{array}$ & \\
\hline rc_q1_corruption_q4 & $\begin{array}{c}8.093 \\
(6.873)\end{array}$ & \\
\hline rc_q1*corruptionQ2_TI & & $\begin{array}{c}5.941 * * * \\
(2.164)\end{array}$ \\
\hline rc_q1*corruptionQ3_TI & & $\begin{array}{c}8.988 * * * \\
(2.817)\end{array}$ \\
\hline rc_q1*corruptionQ4_TI & & $\begin{array}{c}8.591 \\
(6.915)\end{array}$ \\
\hline both_eu_oecd & $6.562 * * *$ & $6.458 * * *$ \\
\hline
\end{tabular}




\begin{tabular}{|c|c|c|}
\hline & (2.193) & $(2.248)$ \\
\hline both_eu_oecd_corruption_q2 & $\begin{array}{l}-2.001 \\
(2.033)\end{array}$ & \\
\hline both_eu_oecd_corruption_q3 & $\begin{array}{c}2.636 \\
(2.773)\end{array}$ & \\
\hline both_eu_oecd_corruption_q4 & Dropped & \\
\hline both_eu_oecd*corruptionQ2_TI & & $\begin{array}{c}2.398 \\
(2.173)\end{array}$ \\
\hline both_eu_oecd*corruptionQ3_TI & & $\begin{array}{c}2.236 \\
(2.905)\end{array}$ \\
\hline Common_border & $\begin{array}{c}-3.822 \\
(2.796)\end{array}$ & $\begin{array}{l}-3.809 \\
(2.794)\end{array}$ \\
\hline both_eu_oecd*Common border & $\begin{array}{c}6.255^{* *} \\
(2.928)\end{array}$ & $\begin{array}{c}6.353 * * \\
(2.924)\end{array}$ \\
\hline Log(gdp) & $\begin{array}{l}1.310^{* *} \\
(0.584)\end{array}$ & $\begin{array}{c}1.496 * * \\
(0.593)\end{array}$ \\
\hline GDP_growth & $\begin{array}{c}0.224 \\
(0.263)\end{array}$ & $\begin{array}{c}0.245 \\
(0.262)\end{array}$ \\
\hline lambda & $\begin{array}{l}-7.337 * \\
(3.827)\end{array}$ & $\begin{array}{c}-6.474 * \\
(3.700)\end{array}$ \\
\hline Constant & $\begin{array}{c}46.20^{* * *} \\
(17.39)\end{array}$ & $\begin{array}{c}41.61^{* *} \\
(17.60)\end{array}$ \\
\hline Firm FE & Yes & Yes \\
\hline Year FE & Yes & Yes \\
\hline Firm*Year FE & Yes & Yes \\
\hline Other control variables & Yes & Yes \\
\hline Observations & 5467 & 5467 \\
\hline R-squared & 0.049 & 0.049 \\
\hline
\end{tabular}




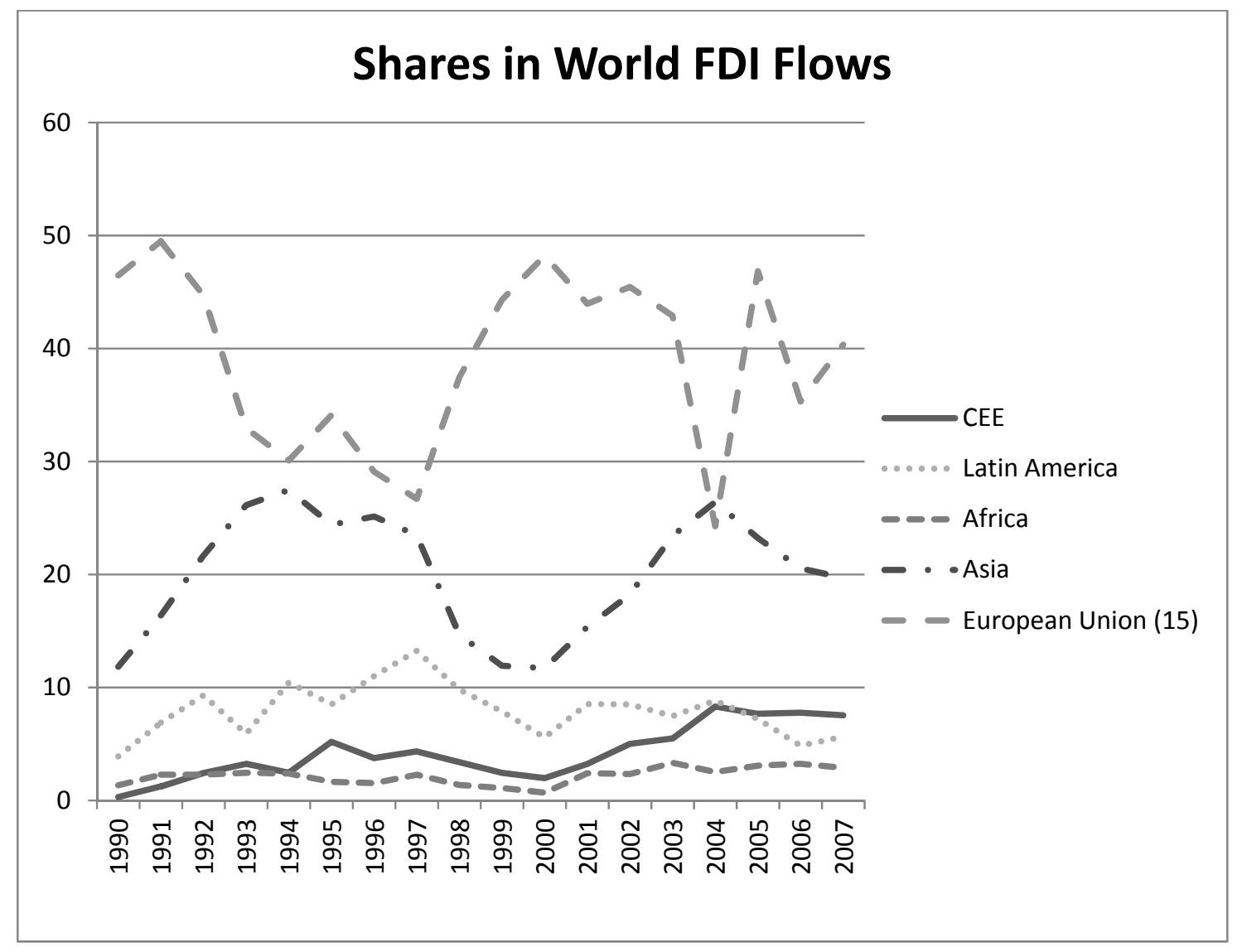


Figure 2: Distribution of foreign ownership 2002-2008

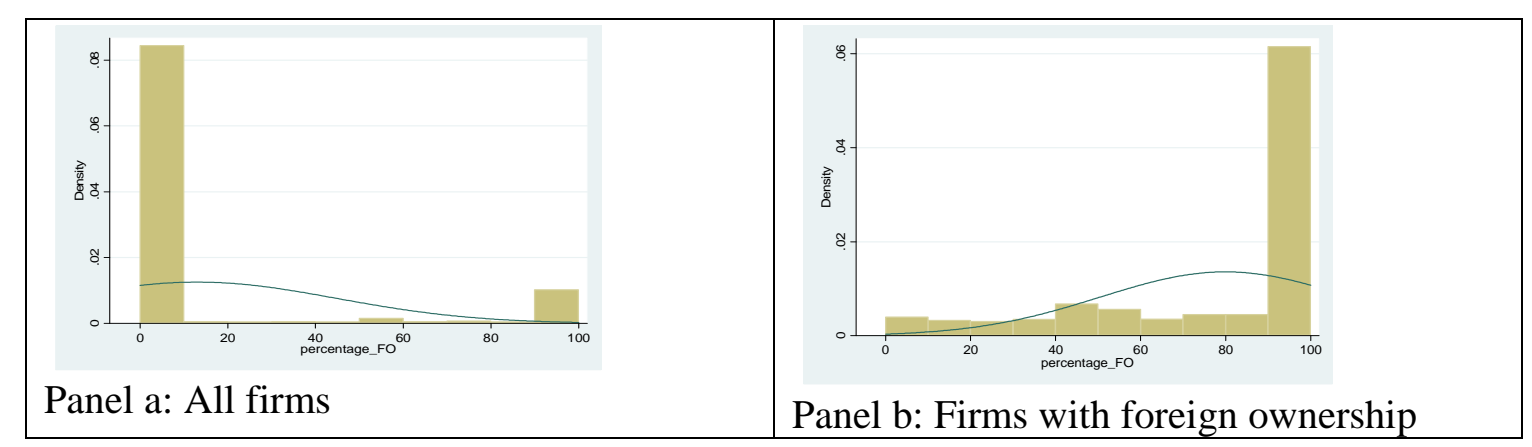

Figure 3. The Epanechnikov kernel plot between percentage foreign ownership and proper host corruption

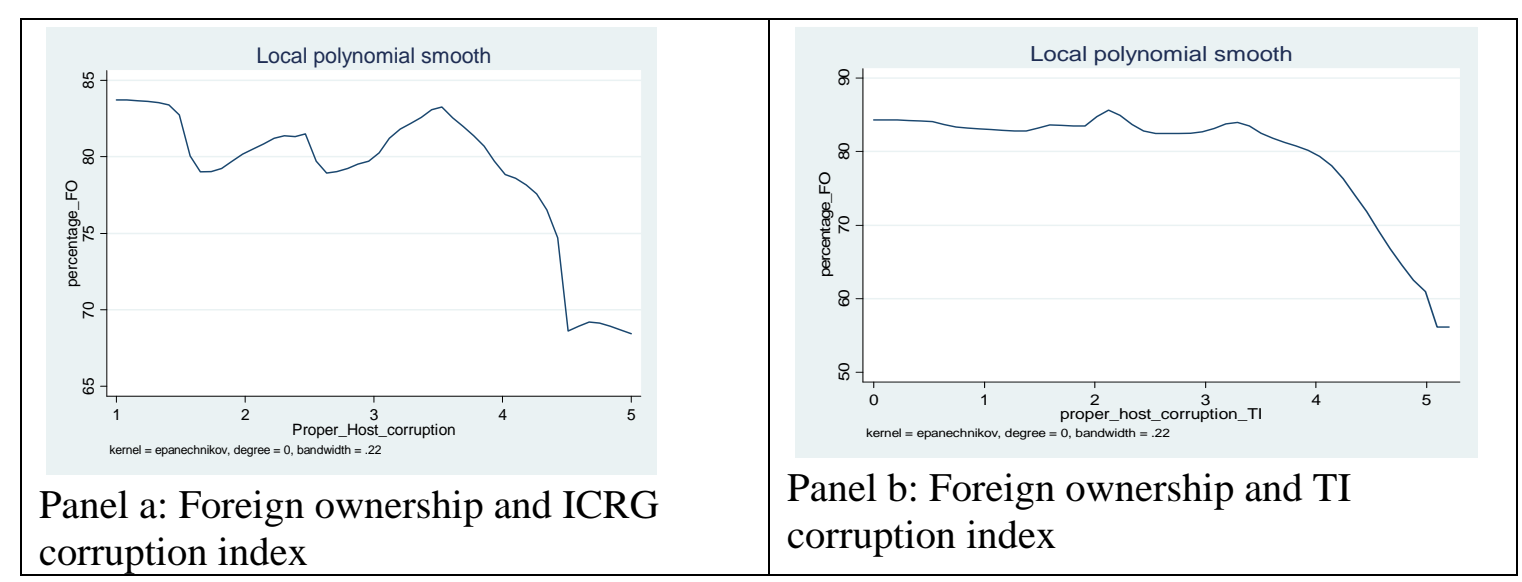

